medRxiv preprint doi: https://doi.org/10.1101/2022.03.01.22271646; this version posted March 4, 2022. The copyright holder for this preprint (which was not certified by peer review) is the author/funder, who has granted medRxiv a license to display the preprint in perpetuity. It is made available under a CC-BY 4.0 International license .

\title{
A gain-of-function GRIA2 variant associated with neurodevelopmental delay and seizures: functional characterization and targeted treatment
}

\section{Short title:}

Analysis of a disease-causing AMPA receptor variant

Ian D. Coombs ${ }^{1^{*}}$, Julie Ziobro ${ }^{2}$, Volodymyr Krotov ${ }^{1}$, Taryn-Leigh Surtees ${ }^{3}$, Stuart G. CullCandy $^{1^{*}}$, Mark Farrant ${ }^{1 *}$

${ }^{1}$ Department of Neuroscience, Physiology and Pharmacology, University College London, London WC1E 6BT, United Kingdom

${ }^{2}$ Department of Pediatrics, University of Michigan, Ann Arbor, Michigan, USA

${ }^{3}$ Department of Neurology, Washington University in St. Louis School of Medicine, St. Louis, Missouri, USA

* Corresponding author

e-mail: i.coombs@ucl.ac.uk (IC)

e-mail: s.cull-candy@ucl.ac.uk (SGCC)

e-mail: m.farrant@ucl.ac.uk (MF)

NOTE: This preprint reports new research that has not been certified by peer review and should not be used to guide clinical practice. 
medRxiv preprint doi: https://doi.org/10.1101/2022.03.01.22271646; this version posted March 4, 2022. The copyright holder for this preprint (which was not certified by peer review) is the author/funder, who has granted medRxiv a license to display the preprint in perpetuity.

\begin{abstract}
AMPA-type glutamate receptors (AMPARs) are tetrameric ligand-gated ion channels formed as different combinations of GluA1-4 subunits encoded by the genes GRIA1-4. Various pathogenic variants of these genes have been described in patients with developmental delay, intellectual disability, autistic spectrum disorder and seizures. Here we report a heterozygous de novo pathogenic missense mutation in GRIA2 (c.1928 C>T, p.A643V) identified in a one-year-old male patient with seizures, developmental delay and failure to thrive. Electrophysiological investigation of heterologously expressed receptors showed GluA2 A643V to exhibit greatly slowed deactivation, and a markedly reduced extent of desensitization, compared with wild-type GluA2. When GluA2 A643V was coexpressed with the transmembrane AMPAR regulatory protein (TARP) $\mathrm{Y} 2$, or with both GluA1 and $\mathrm{Y}^{2}$ to generate TARPed heteromeric receptors, the slowed deactivation and decreased desensitization persisted. We found that the AMPAR negative allosteric modulator perampanel was able to fully block currents from GluA2 A643V/Y2 receptors, albeit with reduced potency compared with wild-type GluA2/y2. The introduction of perampanel to the patient's treatment regimen, alongside a modified Atkins diet, was associated with a marked reduction in seizure number, a resolution of failure to thrive, and clear developmental gains. Our study suggests that AMPAR gain-of-function (GoF) underlies the effect of the GRIA2 variant in our patient, and that perampanel may be beneficial in other patients with GRIA GoF variants.
\end{abstract}


medRxiv preprint doi: https://doi.org/10.1101/2022.03.01.22271646; this version posted March 4, 2022. The copyright holder for this preprint (which was not certified by peer review) is the author/funder, who has granted medRxiv a license to display the preprint in perpetuity. It is made available under a CC-BY 4.0 International license .

\section{Author summary}

Rapid communication between brain cells is mediated by the excitatory neurotransmitter glutamate. Mutations affecting genes that encode glutamate-gated ion channels can result in neurodevelopmental disorders and seizures. In a young male patient, we identified a mutation in the gene responsible for production of GluA2, a key subunit of AMPA-type glutamate receptors. We showed that receptors containing GluA2 produced by this GRIA2 A643V variant were more sensitive to glutamate and gave rise to unusually prolonged or sustained responses, thus causing 'gain-of-function'. We found that receptors affected by this mutation could, nonetheless, be inhibited by the AMPA receptor-targeting antiseizure medication, perampanel. Prompted by this finding we introduced perampanel alongside the patient's ongoing antiseizure medication. This coincided with a decrease in the patient's seizures and clear developmental gains. Taken together, our findings suggest that a GRIA2 gain-of-function mutation can cause neurological disease, that perampanel can be used to directly counteract the effect of the mutation, and that it may be beneficial in other GRIA gain-of-function patients. 
medRxiv preprint doi: https://doi.org/10.1101/2022.03.01.22271646; this version posted March 4, 2022. The copyright holder for this preprint (which was not certified by peer review) is the author/funder, who has granted medRxiv a license to display the preprint in perpetuity.

\section{Introduction}

AMPA-type glutamate receptors (AMPARs) are ligand-gated cation-permeable ion channels that mediate excitatory synaptic transmission throughout the brain. They are formed as homo- or heterotetrameric assemblies of the subunits GluA1-4, encoded by the genes GRIA1, GRIA2, GRIA3 and GRIA4 [1]. AMPARs are critical for the correct development of neuronal circuitry and changes in their number or function underlie activity-dependent strengthening or weakening of synaptic signaling and homeostatic adjustments that maintain neuronal excitability $[2,3]$. AMPAR-mediated excitatory post-synaptic currents typically exhibit fast activation and decay, allowing them to participate in fast, high-frequency signaling. A rapid deactivation of the synaptic current is generally indicative of low AMPAR affinity and efficient clearance of transmitter from the synaptic cleft, although in situations of persistent activity or slow glutamate clearance, channel closure through desensitization also makes an important contribution. Hence, these two parameters are important measures of AMPAR function.

Given the central importance of AMPARs to excitatory synaptic transmission, it is unsurprising that GRIA genes are intolerant to variation. Regions of the transcribed protein that are of particular functional importance are especially intolerant [1], with diseaseassociated de novo variants identified at greatest density in a key conserved motif (SYTANLAAF). This is located towards the extracellular end of the M3 transmembrane helix that forms the extracellular portion of the ion conductance pathway and channel activation gate [4-7]. In general, GRIA disorders are typically associated with developmental delay, intellectual disability, autistic spectrum disorder (ASD) and seizures. As yet, however, there have been insufficient patients identified to form clear genotype-phenotype correlations, and there is still a reliance on extended genetic screens or whole genomic analysis to identify cases. 
medRxiv preprint doi: https://doi.org/10.1101/2022.03.01.22271646; this version posted March 4, 2022. The copyright holder for this preprint (which was not certified by peer review) is the author/funder, who has granted medRxiv a license to display the preprint in perpetuity. It is made available under a CC-BY 4.0 International license .

The GluA2 subunit has a central role in determining AMPAR behavior. It is expressed throughout the brain, with GluA2-containing di- or triheteromeric assemblies being the most prevalent AMPAR subtypes [8-11]. Moreover, most GluA2 pre-mRNA undergoes editing at a site that forms the ion selectivity filter of the mature receptor. This editing results in the genetically encoded glutamine $(Q)$ being read as arginine $(R)$ and renders GluA2(R)containing receptors $\mathrm{Ca}^{2+}$-impermeable [12]. GRIA2 has a Residual Variation Intolerance Score (RVIS) of 10.8\% [13] (http://genic-intolerance.org/), indicating that among the healthy population $89.2 \%$ of all genes have greater variation. Although GRIA2 variants in patients with intellectual disability and neurodevelopmental disorders have been reported to produce predominantly AMPAR loss-of-function [7], gain-of-function variants have nonetheless been identified in other GluA subunits [5, 6]. Accordingly, electrophysiological investigation is required to assess the functional effects of novel variants. The information from such studies may enable a precision medicine approach to treatment. In this regard, while no AMPAR positive modulators are currently available in the clinic, perampanel, a selective AMPAR negative allosteric modulator (NAM) and licensed anti-epileptic drug [14], could be beneficial for GRIA patients with identified gain-of-function variants.

We describe a patient with a novel GRIA2 variant in the SYTANLAAF motif who presented with symptoms including seizures, developmental delay and failure to thrive. Seizures were not eliminated by phenobarbital and levetiracetam nor by trials of additional valproic acid or clobazam, and a modified Atkins diet was subsequently introduced. Here we establish that the variant produces a gain-of-function, conferring slowed AMPAR deactivation, decreased desensitization and increased glutamate potency. Accordingly, we examined the blocking effect of perampanel. Although the drug displayed reduced potency against variant receptors, it was nonetheless a fully effective inhibitor at high doses. Following the addition of perampanel to the patient's treatment plan he demonstrated improved seizure control, resolution of failure to thrive, and has made clear developmental gains. 
medRxiv preprint doi: https://doi.org/10.1101/2022.03.01.22271646; this version posted March 4, 2022. The copyright holder for this preprint (which was not certified by peer review) is the author/funder, who has granted medRxiv a license to display the preprint in perpetuity.

\section{Results}

\section{Clinical findings in a patient with GRIA2 A643V}

The male patient in this study was born at 35-weeks' gestation, following a pregnancy complicated by polyhydramnios. Neurological evaluation was performed at 7 months of age following episodes of back arching and vomiting after feeds. His prior history was notable for gastro-esophageal reflux disease; there was no relevant family medical history. His exam showed decreased muscle tone and mild developmental delay. The EEG at that stage appeared normal (Fig 1a).

At 9 months of age the patient presented to the emergency department with a fever, decreased interaction and new symptoms consisting of dystonic posturing with back arching and upward eye deviation followed by generalized body limpness. Continuous EEG monitoring provided a diagnosis of atypical infantile spasms with myoclonic seizures and a hypsarrhythmia background, with a BASED (Burden of Amplitudes and Epileptiform Discharges) score of 4 [15] (Fig 1b,c). Infantile spasms and hypsarrhythmia were resolved by treatment with ACTH (adrenocorticotropic hormone) and levetiracetam. Brain imaging was performed, with the head CT showing notable extra-axial hyperdensity along the anterior falx. Potentially, this was indicative of a subdural hematoma, which was confirmed by brain MRI and vascular imaging (Fig S1). Further, the MRI exhibited prominent bi-frontal extra-axial space and restricted diffusion along the left insular cortex and left medial temporal lobe (Fig S1). We found no evidence for infectious or traumatic etiologies. At this point, Glutaric aciduria type 1 (GA1) was considered and carnitine supplementation was initiated. We performed an extended epilepsy gene panel, to assess for GA1 (the GCDH gene), in addition to other causes of early infantile epileptic encephalopathies (see below). 
medRxiv preprint doi: https://doi.org/10.1101/2022.03.01.22271646; this version posted March 4, 2022. The copyright holder for this preprint (which was not certified by peer review) is the author/funder, who has granted medRxiv a license to display the preprint in perpetuity. It is made available under a CC-BY 4.0 International license.

a

7 months, normal EEG

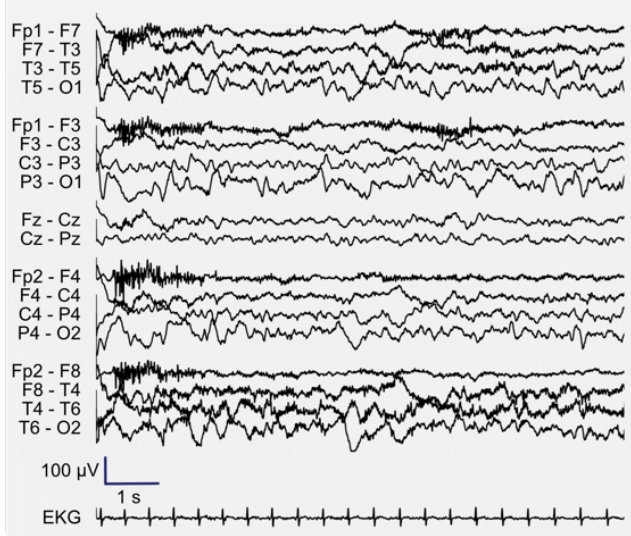

c

9 months, asynchronous infantile spasms

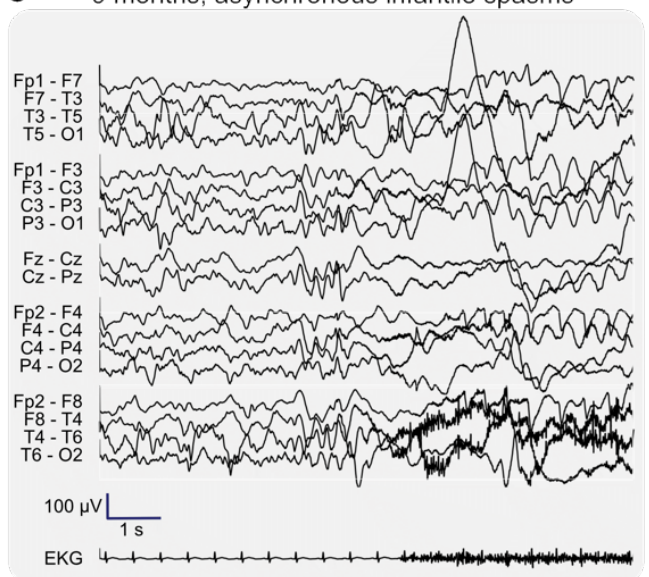

e

\section{M3}

GluA2 A643V 622 VGGVWWFFTLIIISSYTANLAVFLTVERM 650

GlUA1 615 VGGVWWFFTLIIISSYTANLAAFLTVERM 643 GlUA2 622 VGGVWWFFTLIIISSYTANLAAFLTVERM 650 GluA3 633 VGGVWWFFTLIIISSYTANLAAFLTVERM 661 GluA4 623 VGGVWWFFTLIIISSYTANLAAFLTVERM 651

GluK2 636 VGGIWWFFTLIIISSYTANLAAFLTVERM 664 GluN1 632 LGMVWAGFAMIIVASYTANLAAFLVLDRP 660 GlUN2A 630 MVSVWAFFAVIFLASYTANLAAFMIQEEF 658 GluD2 633 MMGAWWLFALIVISSYTANLAAFLTITRI 661 b 9 months, hypsarrhythmia

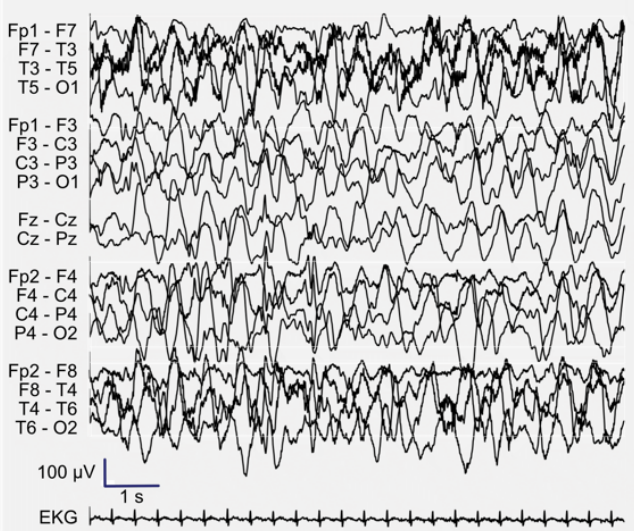

d 14 months, nocturnal asymmetric tonic seizure
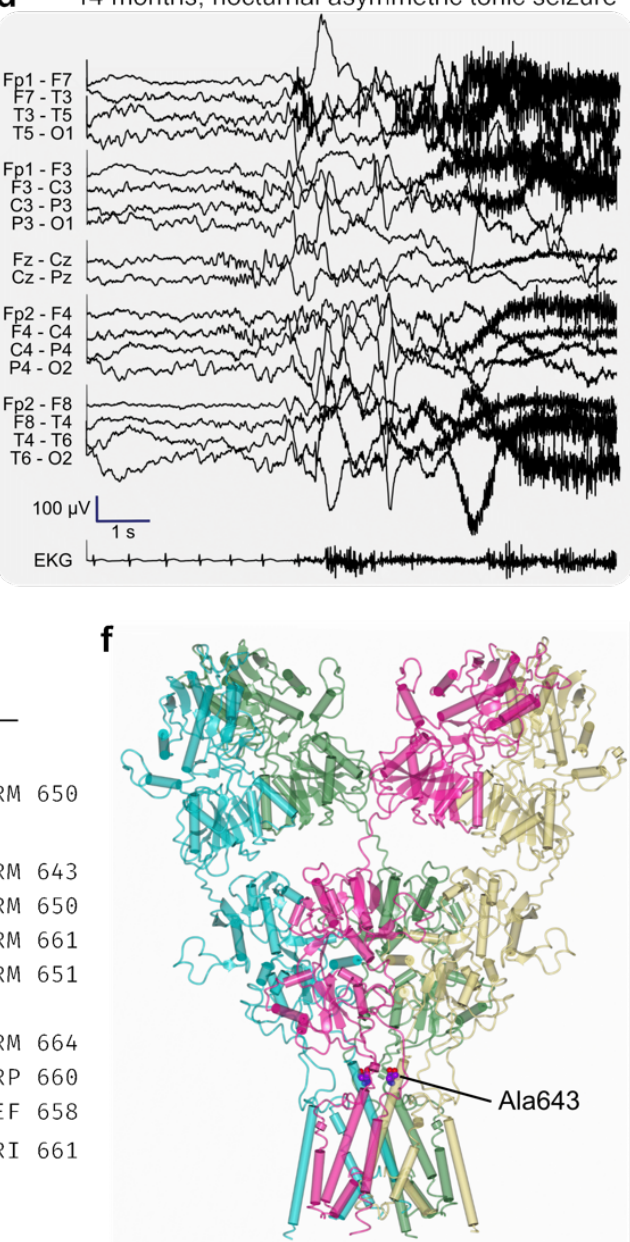

Figure 1. Clinical presentation of a patient with the variant GRIA2 A643V.

a-d) EEG findings. Progression from normal EEG at 7 months of age (a) to hypsarrhythmia (b) with asynchronous infantile spasms (c) at 9 months of age. Hypsarrhythmia resolved with ACTH therapy, but frequent nocturnal asymmetric tonic seizures (d) developed at 14 months of age. e) Sequence alignments highlighting the position of Ala643 in the third membrane region (M3) of the AMPAR subunit. The surrounding region is completely conserved between all four AMPAR subunits, and the SYTANLAAF motif (gray box) is conserved throughout the iGluR superfamily. The gene sequences are from Human GluA1 (NP_001107655.1), Human GluA2 (NP_000817.5), Human GluA3 
medRxiv preprint doi: https://doi.org/10.1101/2022.03.01.22271646; this version posted March 4, 2022. The copyright holder for this preprint (which was not certified by peer review) is the author/funder, who has granted medRxiv a license to display the preprint in perpetuity. It is made available under a CC-BY 4.0 International license .

(NP_015564.5), Human GluA4 (NP_000820.4), Human GluK2 (NP_068775.1), Human GluN1 (NP_015566.1), Human GluN2A (NP_000824.1), and Human GluD2 (NP_001501.2). f) Threedimensional structure of a GluA2 homomeric receptor (PDB ID: 5L1F; [16]) with the position of Ala643 indicated (shown as spheres on all four subunits).

The patient was subsequently admitted at 11 months of age for sub-clinical focal status epilepticus in the setting of respiratory syncytial virus (RSV) infection, requiring introduction of phenobarbital. His global developmental delays became more pronounced during this time period, and asymmetric tonic seizures from sleep developed at 14 months of age (Fig 1d). Seizures occurred every 7-10 days and generally clustered (up to 12 nightly seizures). Meanwhile, he developed significant vomiting and constipation, resulting in failure to thrive his weight fell from the $63 \%$-ile at 6 months of age to the $0.07 \%$-ile by 20 months of age. Seizures were not eliminated by trials of additional valproic acid or clobazam, and a modified Atkins diet was subsequently introduced. This diet was later supplemented with mediumchain triglycerides (MCTs).

Our genetic analysis revealed a heterozygous variant in GRIA2 (c.1928 C>T, p.A643V, NM_001083619.1) with no other variants of clinical interest (Fig 1e). The variant was novel, being absent from the Genome Aggregation Database (gnomAD) and the ClinVar database and was confirmed as de novo by trio sequencing. GRIA2 Ala643 is located at the lurcher site [17] in the highly conserved sequence (SYTANLAㅌF) that forms the upper AMPAR ion channel gate (Fig 1f). Bioinformatic predictions suggested that the variant was likely to be pathogenic - SIFT pathogenic, score 0 [18]; polyphen 2, probably damaging, score 0.999 [19]; VARITY R, score 0.953 [20]. Indeed, variants at this site have previously been suggested as disease-causing for GRIA1 [6], GRIA4 [4], and GRIA3 (present in ClinVar database) (Fig 1f). Previous examination of GRIA2 missense variants underlying neurodevelopmental disorders and seizures, found them to cause primarily a loss-of-function (LoF) [7]. However, mutation at the analogous site in GRIA1 (A636T) produces a gain-of- 
medRxiv preprint doi: https://doi.org/10.1101/2022.03.01.22271646; this version posted March 4, 2022. The copyright holder for this preprint (which was not certified by peer review) is the author/funder, who has granted medRxiv a license to display the preprint in perpetuity. It is made available under a CC-BY 4.0 International license .

function (GoF) due to destabilization of the closed gate [17] (Fig 1f). It was therefore crucial to understand the impact of the valine variant on AMPAR function.

\section{GluA2 A643V causes gain-of-function}

To determine the functional effect of the GRIA2 A643V variant we expressed GluA2(Q) wildtype or A643V subunits in HEK293 cells and compared their responses to rapid glutamate application in outside-out patches (Fig 2a-c). The homomeric GluA2(Q) A643V receptors were functional and produced currents with distinct kinetic features. For currents evoked using short glutamate applications $(10 \mathrm{mM},-60 \mathrm{mV}, 1-2 \mathrm{~ms})$ the weighted time constant of deactivation ( $\mathrm{T}_{\mathrm{w} \text {, deact }}$ ) was roughly 7 -fold greater with A643V compared to wild-type (Table 1) (Fig 2a,d). With long glutamate applications $(10 \mathrm{mM},-60 \mathrm{mV}, 500 \mathrm{~ms})$ we found that the A643V variant markedly affected AMPAR desensitization. The weighted time constant ( $T_{w}$, des $)$ was almost double that of wild-type and the fractional steady-state current $\left(I_{\mathrm{ss}}\right)$ was increased more than 50 -fold, indicating that the extent of desensitization was greatly reduced (Table 1) (Fig 2b,e). Consistent with this large steady-state current, the recovery from desensitization of the variant was more than twice as fast as that of the wild-type (Table 1) (Fig 2c,f). Taken together, these results indicate that A643V is a GoF variant. We found no evidence that the variant altered GluA2 pore properties, as non-stationary fluctuation analysis revealed no effect on weighted mean channel conductance or peak open probability (Table 1) (Fig 2b,g). 
a

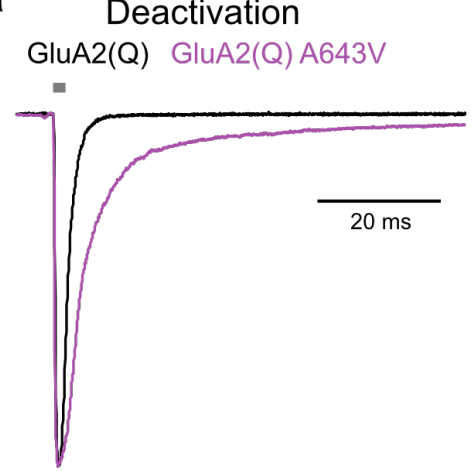

b

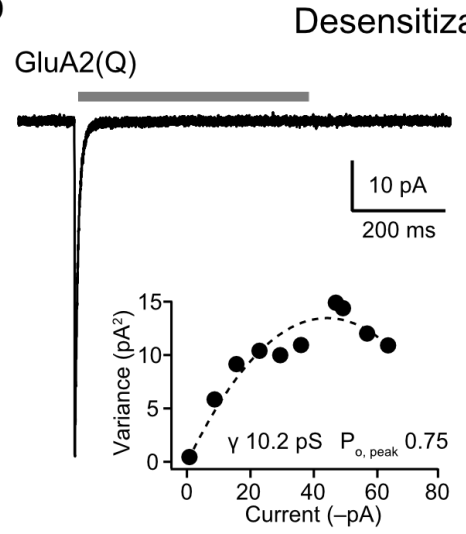

GluA2(Q) A643V

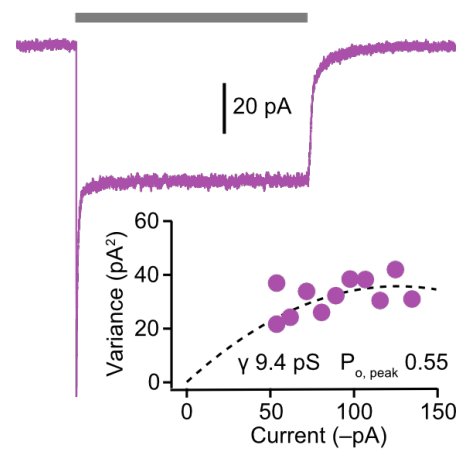

C Recovery from desensitization
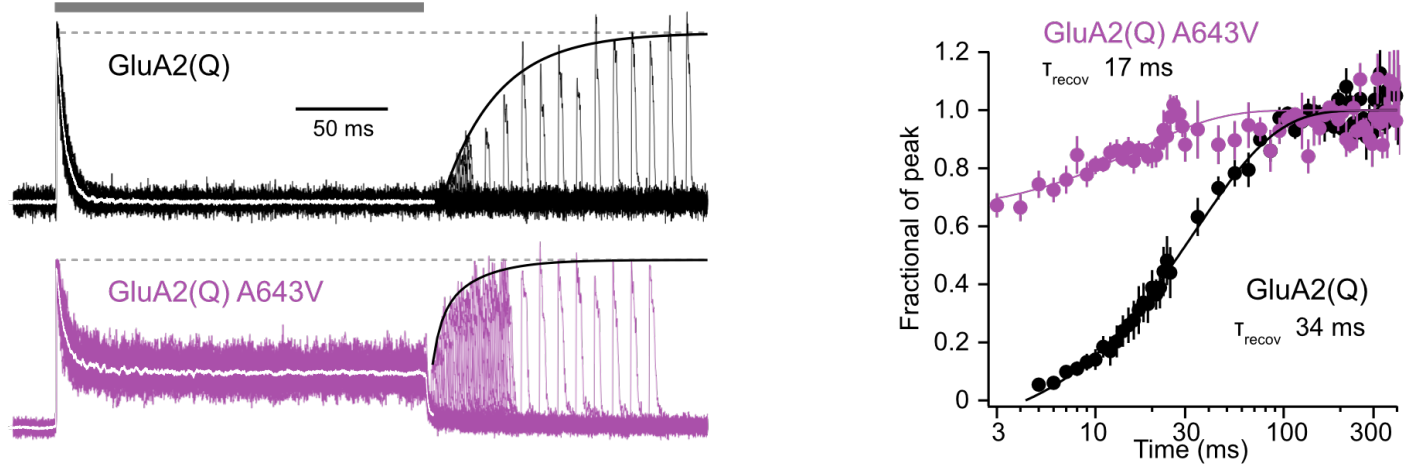

d

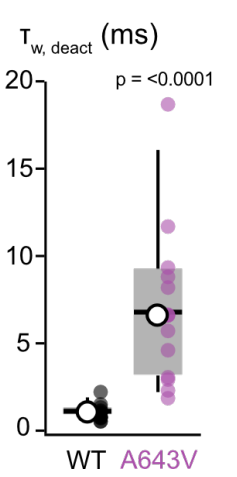

e $T_{w, \text { des }}(\mathrm{ms})$

$I_{\text {ss }} I_{\text {peak }}(\%)$

f $\mathrm{T}_{\text {recov }}(\mathrm{ms})$

g $Y(p S)$
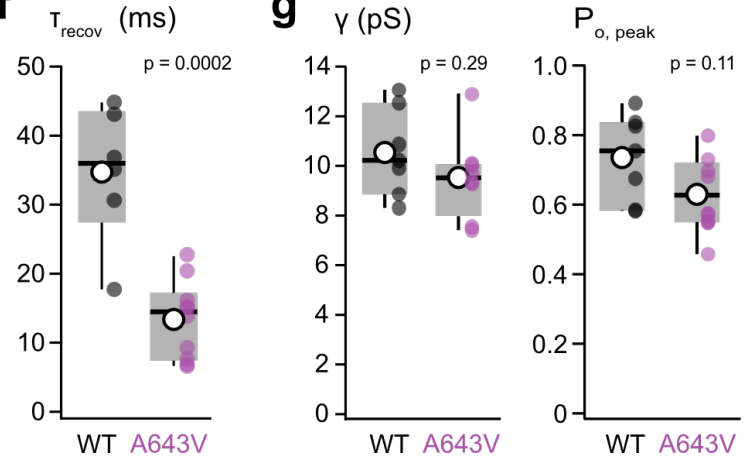

Figure 2. The GRIA2 A643V variant generates a gain-of-function.

a) Representative outside-out patch responses (10 mM glutamate, $1 \mathrm{~ms},-60 \mathrm{mV}$; gray bar) from HEK293 cells transfected with wild-type (WT) GluA2(Q) (black) or GluA2(Q) A643V (purple) (superimposed). b) Representative outside-out patch responses to $500 \mathrm{~ms}$ applications of glutamate (10 mM, -60 mV). Insets show corresponding current-variance relationships and estimated channel conductance $(\mathrm{Y})$ and peak open probability $\left(P_{\mathrm{o}}\right.$, peak). c) Representative outside-out patch responses showing recovery from desensitization; superimposed currents (inverted for display) evoked by steady-state glutamate application ( $200 \mathrm{~ms},-60 \mathrm{mV}$; gray bar) and subsequent $10 \mathrm{~ms}$ applications of glutamate, applied at increasing intervals. Averaged currents before recovery shown as white traces. Solid black lines are exponential fits of peak current recovery. Right; pooled recovery timecourse plot for GluA2(Q) $(n=10)$ and GluA2(Q) A643V $(n=6)$. Symbols and error bars indicate mean values with s.e.m., and the solid lines are exponential fits, yielding the indicated Trecov values. d) Pooled Tw, deact data for GluA2(Q) ( $n=16)$ and GluA2(Q) A643V $(n=13)$. Box-and-whisker plots indicate the median (black line), the 25-75th percentiles (box), and the 10-90th percentiles (whiskers); filled circles are data from individual patches and open circles indicate means. e) Pooled $T_{w}$, des and $I_{\mathrm{ss}}$ data for GluA2(Q) ( $n=31)$ and GluA2(Q) A643V ( $=33)$ from 500 ms glutamate applications. f) Pooled T recov data for GluA2(Q) ( $n=6)$ and GluA2(Q) A643V $(n=10)$. g) Pooled weighted mean conductance $(Y)$ 
medRxiv preprint doi: https://doi.org/10.1101/2022.03.01.22271646; this version posted March 4, 2022. The copyright holder for this preprint (which was not certified by peer review) is the author/funder, who has granted medRxiv a license to display the preprint in perpetuity. It is made available under a CC-BY 4.0 International license.

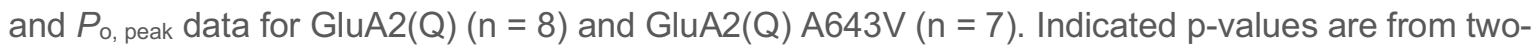
sided approximate permutation t-tests comparing wild-type (WT) and A643V variant (Table 1).

We next examined the effect of A643V on glutamate potency. We first recorded responses to various glutamate concentrations in the presence of the positive allosteric modulator (PAM) cyclothiazide to limit desensitization (Fig 3a, b). We found that glutamate displayed increased potency at A643V AMPARs, with the concentration producing half-maximal current $\left(E C_{50, C T z}\right)$ being reduced by 5 -fold (Table 1$)$. We also examined the concentration dependence of glutamate-evoked peak currents in the absence of cyclothiazide (Fig 3c, d). where again the variant increased glutamate potency (Table 1). These results are consistent with A643V being a GoF variant.

\begin{tabular}{|c|c|c|c|c|}
\hline & GluA2(Q) & GluA2(Q) A643V & Unpaired mean difference $[95 \% \mathrm{Cl}]$ & p-value \\
\hline $\mathrm{T}_{\mathrm{w}, \text { deact }}(\mathrm{ms})$ & $1.0 \pm 0.1(16)$ & $6.9 \pm 1.3(13)$ & $5.9[4.0,9.0]$ & $<0.0001$ \\
\hline $\mathrm{T}_{\mathrm{w}, \mathrm{des}}(\mathrm{ms})$ & $5.1 \pm 0.4(31)$ & $9.5 \pm 1.7(33)$ & $4.4[1.7,8.3]$ & 0.011 \\
\hline$I_{\text {ss }} / /_{\text {peak }}(\%)$ & $0.9 \pm 0.2(31)$ & $47.4 \pm 2.0(33)$ & $46.5[42.2,50.3]$ & $<0.0001$ \\
\hline $\mathrm{T}_{\text {recov }}(\mathrm{ms})$ & $34.7 \pm 4.0(6)$ & $13.4 \pm 1.8(10)$ & $-21.3[-28.0,-12.1]$ & 0.0002 \\
\hline Conductance (pS) & $10.5 \pm 0.7(7)$ & $9.5 \pm 0.6(8)$ & $-1.0[-2.6,0.7]$ & 0.29 \\
\hline$P_{\text {o, peak }}$ & $0.74 \pm 0.12(7)$ & $0.63 \pm 0.11(8)$ & $-0.11[-0.21,0.01]$ & 0.11 \\
\hline Glu $E C_{50} \mathrm{ctz}(\mu \mathrm{M})$ & $322 \pm 63(5)$ & $59 \pm 9(6)$ & $-263[-402,-177]$ & $<0.0001$ \\
\hline \multirow[t]{2}{*}{ Glu $E C_{50 \text { peak }}(\mathrm{mM})$} & $1.14 \pm 0.20(5)$ & $0.15 \pm 0.02(5)$ & $-0.99[-1.29,-0.59]$ & $<0.0001$ \\
\hline & GluA1/2(R) & GluA1/2(R) A643V & & \\
\hline $\mathrm{T}_{\mathrm{w}, \text { deact }}(\mathrm{ms})$ & $2.0 \pm 0.4(7)$ & $18.6 \pm 6.8(6)$ & $16.6[7.8,36.8]$ & 0.0007 \\
\hline $\mathrm{T}_{\mathrm{w}, \text { des }}(\mathrm{ms})$ & $7.2 \pm 1.0(9)$ & $32.7 \pm 8.5(5)$ & $25.5[15.3,50.4]$ & 0.0002 \\
\hline$I_{\text {ss }} / I_{\text {peak }}(\%)$ & $2.6 \pm 1.0(9)$ & $34.2 \pm 8.7(5)$ & $31.6[15.1,45.6]$ & 0.0005 \\
\hline
\end{tabular}

Table 1. Summary of GluA2 A643V effects on homomeric and heteromeric AMPARs.

Data are presented as mean \pm standard error (s.e.m.) from $n$ patches. Unpaired mean differences are given with their $95 \%$ bias corrected and accelerated $(\mathrm{BCa})$ confidence intervals [upper bound, lower bound], calculated from 5000 bootstrap resamples. All p-values were calculated using a nonparametric two-sided approximate permutation t-test, with 10000 bootstrap replicates. The $p$-values are reported as equalities, unless $<0.0001$. 
medRxiv preprint doi: https://doi.org/10.1101/2022.03.01.22271646; this version posted March 4, 2022. The copyright holder for this preprint (which was not certified by peer review) is the author/funder, who has granted medRxiv a license to display the preprint in perpetuity. It is made available under a CC-BY 4.0 International license .

Having established that GluA2 A643V produces a GoF in homomeric Q/R unedited receptors, we next examined its impact when incorporated into heteromeric receptors. Specifically, we co-expressed GluA1 and Q/R edited GluA2, the AMPAR subunits that predominate in the hippocampus [10, 21]. As these preferentially co-assemble into tetramers containing two copies of GluA1 and two copies of GluA2, we speculated that the functional effect of the A643V variant might be weakened in the presence of GluA1. However, when we recorded currents at $+60 \mathrm{mV}$ with $100 \mu \mathrm{M}$ NASPM in the intracellular (pipette) solution to block any GluA1 homomers [22], we found that the variant slowed deactivation and markedly reduced desensitization (Fig $\mathbf{4 a}, \mathbf{b}$ ). Thus, $\mathrm{T}_{\mathrm{w} \text {, deact }}$ was increased nearly $10-$ fold, $\mathrm{T}_{\mathrm{w} \text {, des }}$ was increased more than 4 -fold, and $I_{\text {ss }}$ was increased by more than 10 -fold (Table 1). Taken together, these data show that GluA2 A643V imparts a marked GoF when the variant is part of a heteromeric GluA1/2 assembly. 
medRxiv preprint doi: https://doi.org/10.1101/2022.03.01.22271646; this version posted March 4, 2022. The copyright holder for this preprint (which was not certified by peer review) is the author/funder, who has granted medRxiv a license to display the preprint in perpetuity. It is made available under a CC-BY 4.0 International license .

a

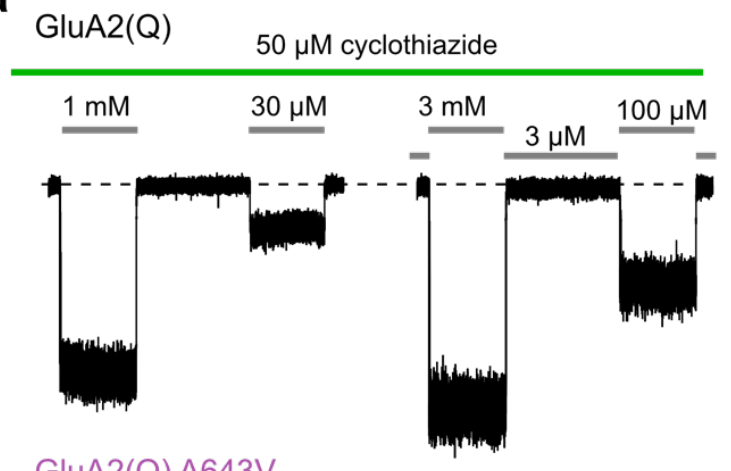

GluA2(Q) A643V

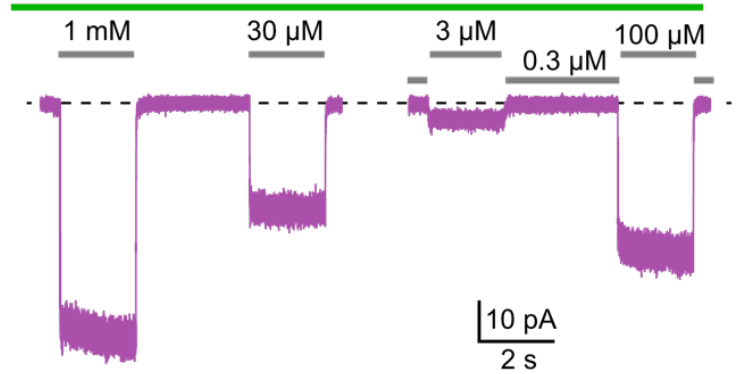

C

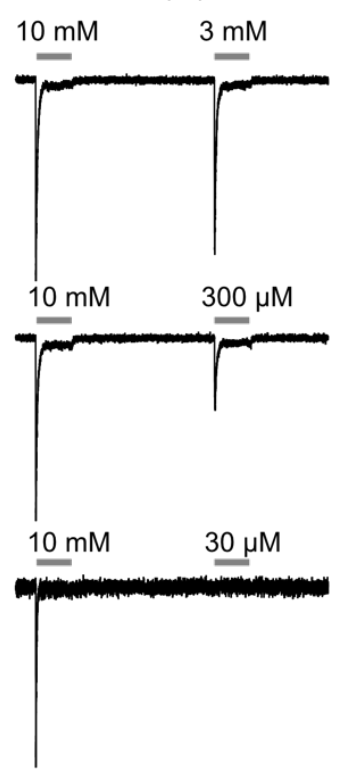

GluA2(Q) A643V

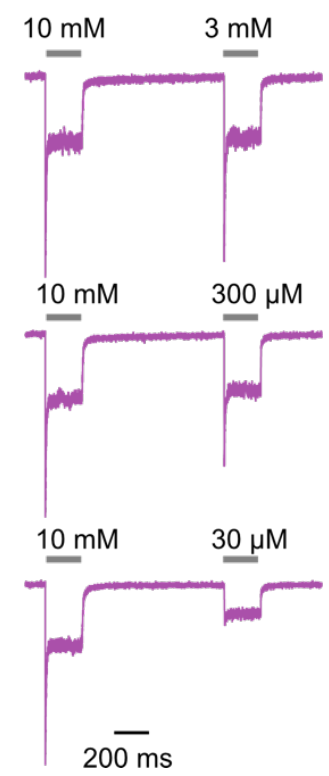

b

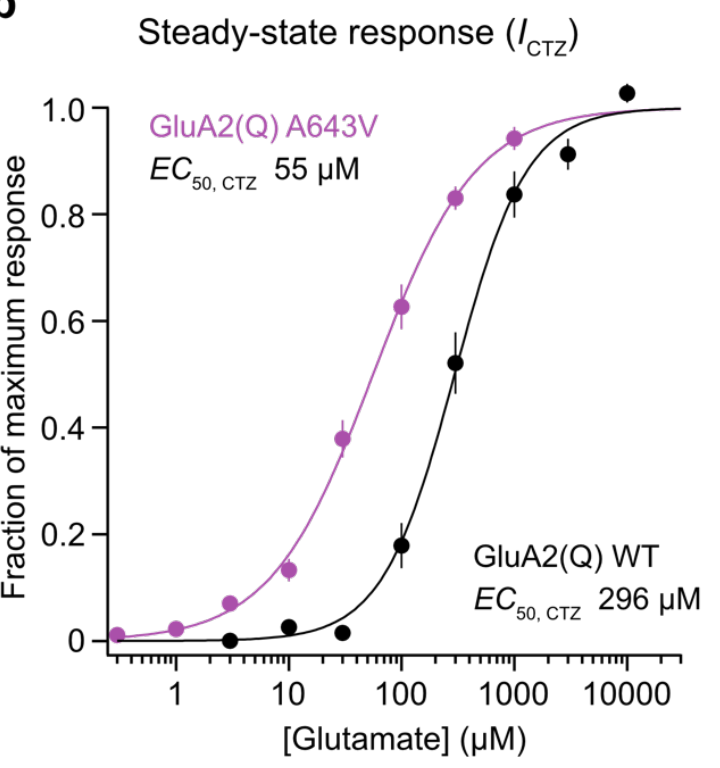

d Peak response

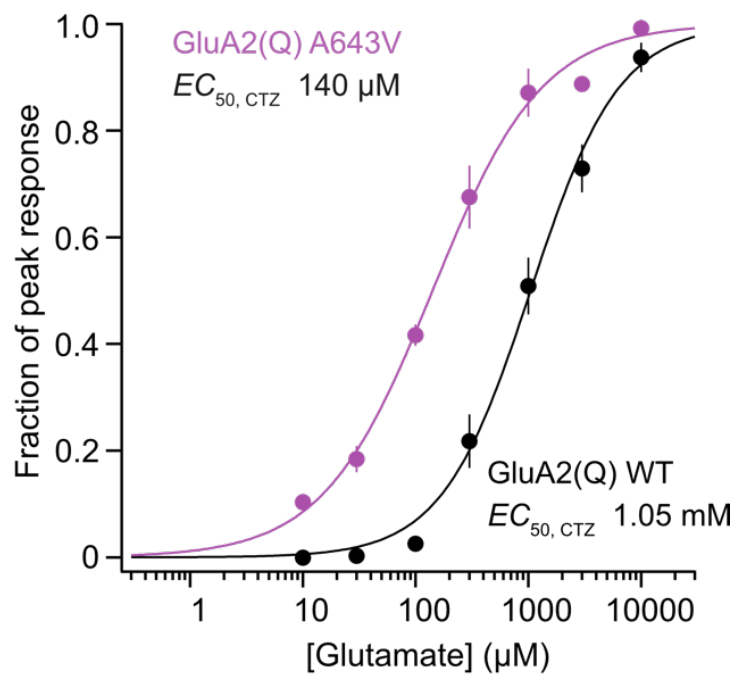

Figure 3. The GRIA2 A643V variant increases glutamate potency.

a) Representative currents evoked by different concentrations of glutamate (gray bars) applied to outside-out patches from HEK293 cells transfected with wild-type (WT) GluA2(Q) (black) or GluA2(Q) A643V (purple) in the presence of $50 \mu \mathrm{M}$ cyclothiazide (green bar). b) Pooled normalized concentration-response curves for glutamate in the presence of cyclothiazide for GluA2(Q) $(n=5)$ and GluA2(Q) A643V ( $n=6)$. Symbols and error bars indicate mean values with s.e.m., and the solid lines are fits to the Hill equation, yielding the indicated $E C_{50}$ values. Table 1 reports the statistical analysis of $E C_{50}$ values obtained from separate fits of the data from individual patches. c) Representative glutamate responses in the absence of cyclothiazide. Each sweep contained an initial jump into 10 $\mathrm{mM}$ glutamate, for normalization, followed by a jump into a lower glutamate concentration. d) Pooled normalized peak-current concentration-response curves for GluA2(Q) $(n=5)$ and GluA2(Q) A643V ( = 5) (details as in b). 
medRxiv preprint doi: https://doi.org/10.1101/2022.03.01.22271646; this version posted March 4, 2022. The copyright holder for this preprint (which was not certified by peer review) is the author/funder, who has granted medRxiv a license to display the preprint in perpetuity. It is made available under a CC-BY 4.0 International license .

Native AMPAR assemblies contain auxiliary proteins, the most prevalent being the transmembrane AMPAR regulatory proteins (TARPs) [23, 24]. As these affect many biophysical and pharmacological AMPAR properties [25], we next considered the effect of the A643V variant on AMPAR assemblies that contained the prototypical TARP $\mathrm{Y} 2$ (stargazin). Responses to short glutamate applications showed that, as seen in absence of TARP, $\mathrm{T}_{\mathrm{w} \text {, deact }}$ was increased for both homomeric and heteromeric receptors ( $10-$ and 3fold, respectively) (Fig 5a,b) (Table 2). In response to long glutamate applications the desensitization of GluA2(Q)/Y2 and GluA1/2(R)/Y2 was not slowed by the presence of the variant. However, $I_{s s}$ was greatly increased (Fig 5c,d) (Table 2). Thus, in terms of slowed deactivation and decreased steady-state desensitization, GluA2 A643V produces GoF in all the AMPAR assemblies we examined. 
medRxiv preprint doi: https://doi.org/10.1101/2022.03.01.22271646; this version posted March 4, 2022. The copyright holder for this preprint (which was not certified by peer review) is the author/funder, who has granted medRxiv a license to display the preprint in perpetuity. It is made available under a CC-BY 4.0 International license .

\section{a}
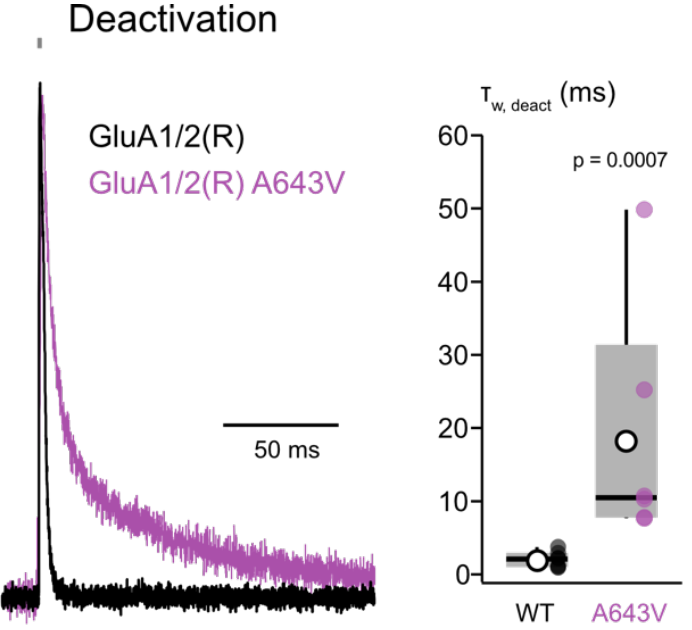

b

Desensitization

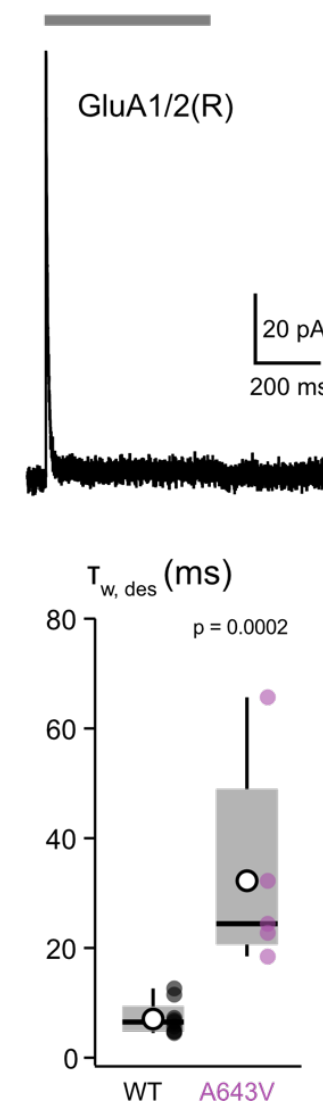

Figure 4. GRIA2 A643V alters the properties of GluA1/2 heteromeric AMPARs.

a) Representative deactivating outside-out patch responses (10 mM glutamate, $1 \mathrm{~ms},+60 \mathrm{mV}$; gray bar) from HEK293 cells transfected with GluA1 and GluA2(R) (black) or GluA1 and GluA2(R) A643V (purple) (superimposed). Right: pooled Tw, deact data for wild-type (WT) GluA1/GluA2(R) $(n=7)$ and GluA1/GluA2(R) A643V ( $n=6)$. Boxplots as in Fig 2. b) Representative desensitizing responses (10 $\mathrm{mM}$ glutamate, $500 \mathrm{~ms}$; gray bar) from WT and A643V heteromers. c) Pooled $\mathrm{T}_{\mathrm{w}}$, des and $I_{\mathrm{ss}}$ data for GluA1/GluA2(R) ( $n=9)$ and GluA1/GluA2(R) A643V $(n=5)$. Indicated $p$-values are from two-sided approximate permutation t-tests comparing wild-type (WT) and A643V variant (Table 1). 
a

a

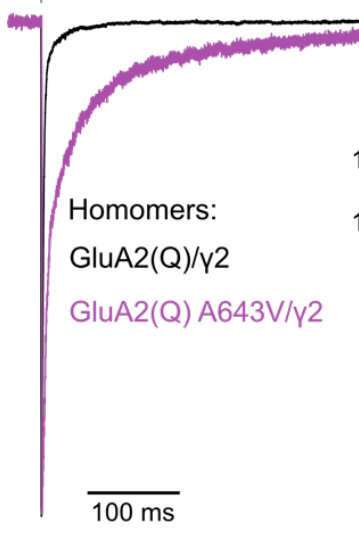

C

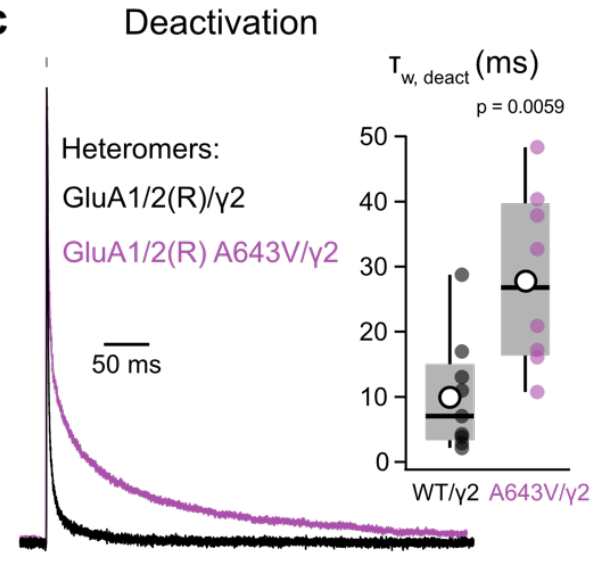

b

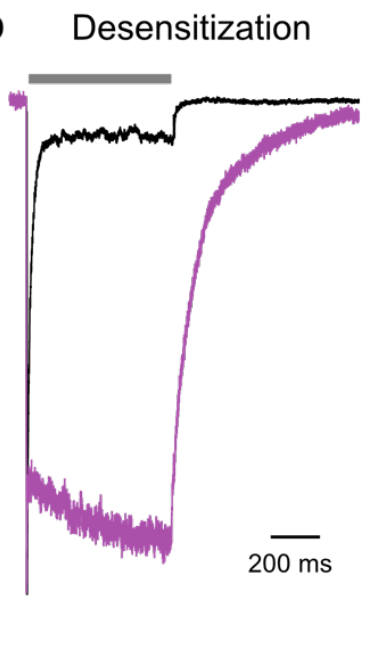

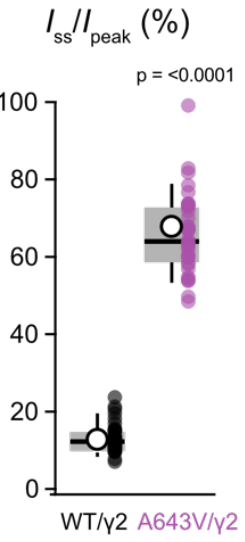
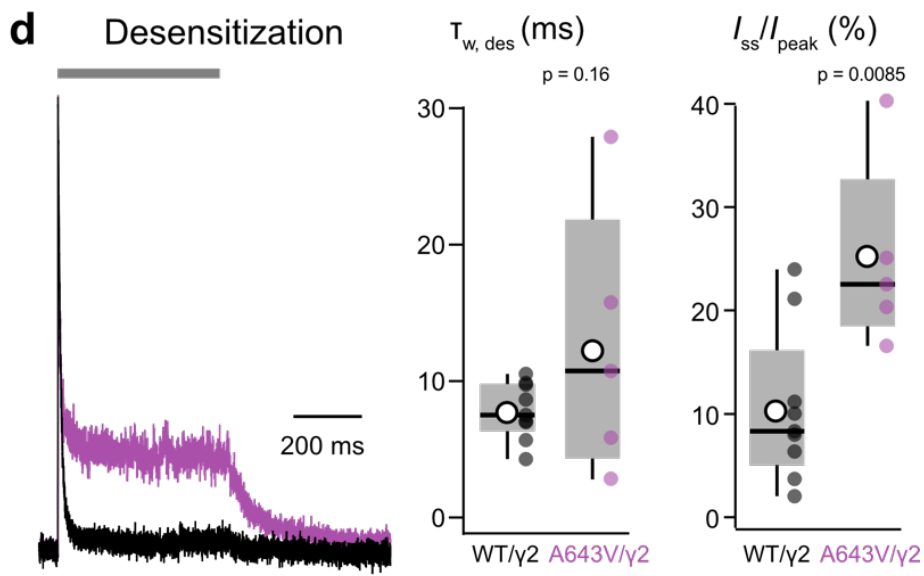

Figure 5. GRIA2 A643V alters the properties of TARP-associated homomeric and heteromeric AMPARs.

a) Representative superimposed deactivating outside-out patch responses (10 mM glutamate, $1 \mathrm{~ms}$, $-60 \mathrm{mV}$; gray bar) from HEK293 cells transfected with GluA2(Q) and TARP y2 (black) or GluA2(Q) A643V and $\mathrm{Y} 2$ (purple). Inset: pooled $\mathrm{T}_{\mathrm{w} \text {, deact }}$ data for wild-type (WT)/Y2 and A643V/Y2 (box-andwhisker plot as in Fig 2). b) Representative superimposed desensitizing outside-out patch responses (10 mM glutamate, $500 \mathrm{~ms},-60 \mathrm{mV}$; gray bar) from GluA2(Q)/ 2 2 (black) and GluA2(Q) A643V/ץ2 (purple). Right: pooled $T_{w}$, des and $I_{s s}$ data c) Representative superimposed deactivating currents from heteromeric receptors with TARP $\mathrm{y} 2$; GluA1/GluA2(R)/ 2 (black) or GluA1/GluA2(R) A643V/Y2 (purple) (10 mM glutamate, $1 \mathrm{~ms},+60 \mathrm{mV}$; gray bar). Inset: pooled $\mathrm{T}_{\mathrm{w}}$ deact data. d) Representative superimposed desensitizing responses ( $10 \mathrm{mM}$ glutamate, $500 \mathrm{~ms},+60 \mathrm{mV}$ ) from GluA1/GluA2(R)/ $/ 2$ (WT; black) and GluA1/GluA2(R) A643V/Y2 (purple). Right: pooled $T_{w}$, des and $I_{s s}$ data. Indicated pvalues are from two-sided approximate permutation t-tests comparing wild-type (WT) and A643V variant (Table 1). 
medRxiv preprint doi: https://doi.org/10.1101/2022.03.01.22271646; this version posted March 4, 2022. The copyright holder for this preprint (which was not certified by peer review) is the author/funder, who has granted medRxiv a license to display the preprint in perpetuity. It is made available under a CC-BY 4.0 International license .

\begin{tabular}{|c|c|c|c|c|}
\hline & GluA2(Q)/Y2 & GluA2(Q) A643V/Y2 & Unpaired mean difference $[95 \% \mathrm{Cl}]$ & p-value \\
\hline $\mathrm{T}_{\mathrm{w}, \text { deact }}(\mathrm{ms})$ & $3.6 \pm 0.6(11)$ & $50.5 \pm 7.2(17)$ & $46.9[35.9,64.1]$ & $<0.0001$ \\
\hline $\mathrm{T}_{\mathrm{w}, \mathrm{des}}(\mathrm{ms})$ & $13.6 \pm 0.8(29)$ & $11.6 \pm 2.3(36)$ & $-2.0[-5.6,4.2]$ & 0.48 \\
\hline$I_{\text {ss }} / I_{\text {peak }}(\%)$ & $14.1 \pm 2.2(29)$ & $66.2 \pm 1.7(37)$ & $52.1[46.2,57.2]$ & $<0.0001$ \\
\hline PER $I C_{50 \text { peak }}(\mu \mathrm{M})$ & $0.13 \pm 0.02(6)$ & $1.29 \pm 0.38(4)$ & $1.17[0.66,1.98]$ & 0.0052 \\
\hline \multirow[t]{2}{*}{ PER $/ C_{50}$ s-s $(\mu \mathrm{M})$} & & $3.08 \pm 0.26(4)$ & & \\
\hline & GluA1/2(R)/Y2 & GluA1/2(R) A643V/Y2 & & \\
\hline $\mathrm{T}_{\mathrm{w}, \text { deact }}(\mathrm{ms})$ & $10.0 \pm 2.9(9)$ & $28.0 \pm 4.8(8)$ & $18.0[7.71,28.2]$ & 0.0059 \\
\hline $\mathrm{T}_{\mathrm{w}, \mathrm{des}}(\mathrm{ms})$ & $7.8 \pm 0.7(9)$ & $12.6 \pm 4.4(5)$ & $4.8[-1.53,14.7]$ & 0.16 \\
\hline$I_{\text {ss }} / I_{\text {peak }}(\%)$ & $10.5 \pm 2.5(9)$ & $25.0 \pm 4.1(5)$ & $14.4[6.9,23.9]$ & 0.0085 \\
\hline
\end{tabular}

Table 2. Summary of GluA2 A643V effects on homomeric and heteromeric AMPARs expressed with TARP y2.

Data are presented as mean \pm standard error (s.e.m.) from $n$ patches. For GluA2(Q) A643V/Y2, the perampanel (PER) $/ C_{50}$ is shown for both the initial peak and steady-state (s-s) currents. Details as in Table 1.

\section{Perampanel inhibition of GluA2 A643V}

As we found the A643V mutation to cause a clear GoF, we next sought to examine the effect of the AMPAR NAM perampanel, a licensed anti-epileptic drug [14]. For both GluA2(Q)/Y2 and GluA2(Q) A643V/Y2 perampanel inhibited the response to glutamate (Fig 6a). However, perampanel was roughly 10 times less potent against the variant than the wild-type (when assessing its effects on the initial peaks of the glutamate-evoked currents) (Fig 6b) (Table 2). In some recordings the response of GluA2(Q) $A 643 V / \gamma 2$ in the presence of perampanel showed a slow 'run-up' (Fig 6b). When assessing the steady-state responses, rather than the initial peaks, the perampanel potency was reduced (Table 2). Of note the perampanelbound crystal structure of GluA2(Q) [16] shows that the perampanel binding site is adjacent to the channel gate and the Ala643 residue, potentially accounting for the decreased potency of the drug against the variant receptors (Fig 6c). 
medRxiv preprint doi: https://doi.org/10.1101/2022.03.01.22271646; this version posted March 4, 2022. The copyright holder for this preprint (which was not certified by peer review) is the author/funder, who has granted medRxiv a license to display the preprint in perpetuity. It is made available under a CC-BY 4.0 International license .

a

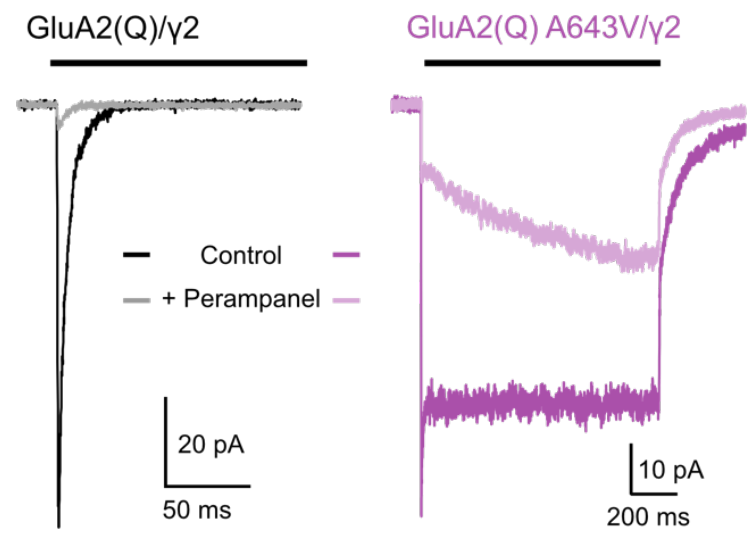

C

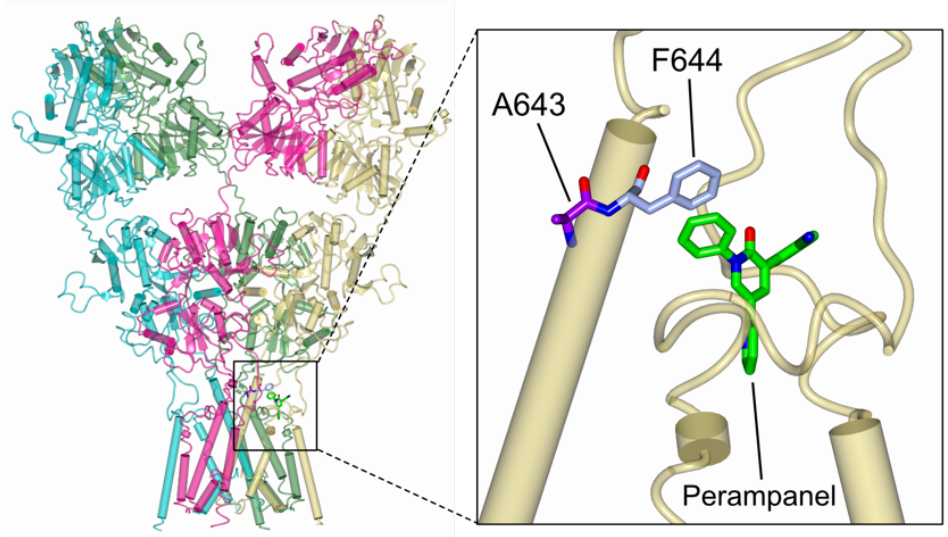

e

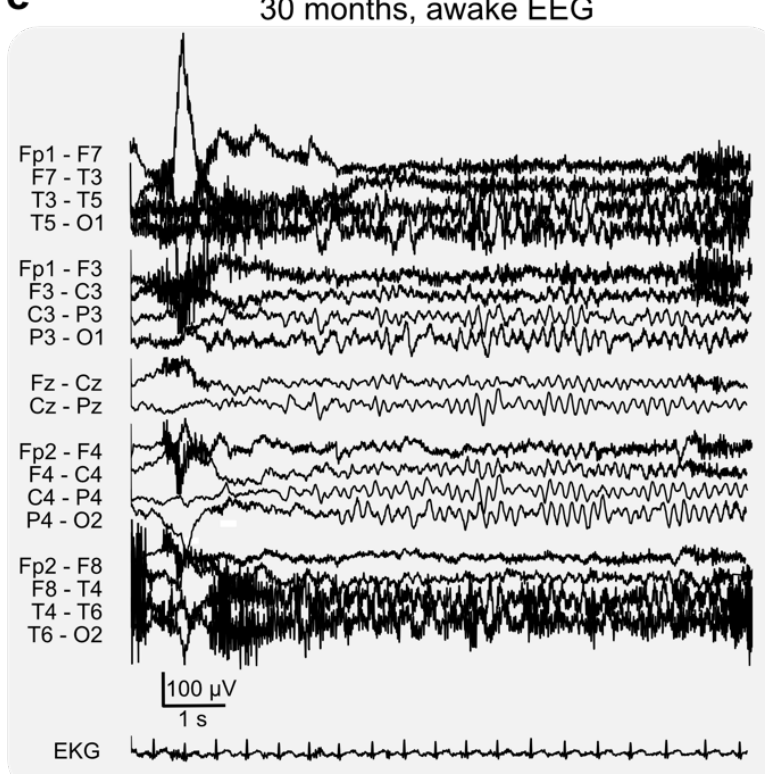

b

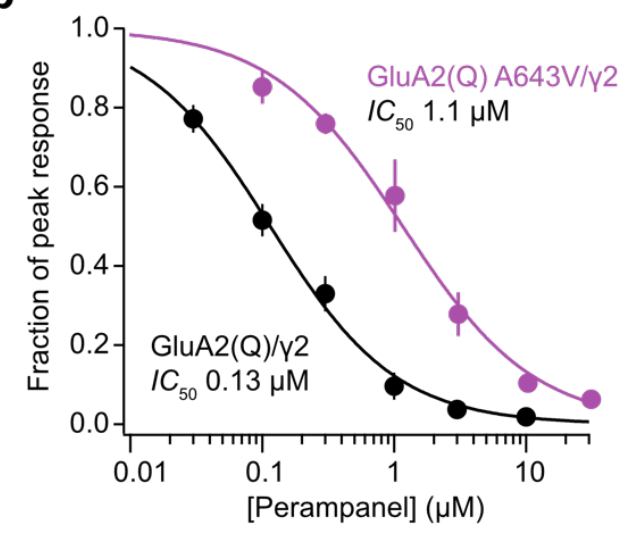

d

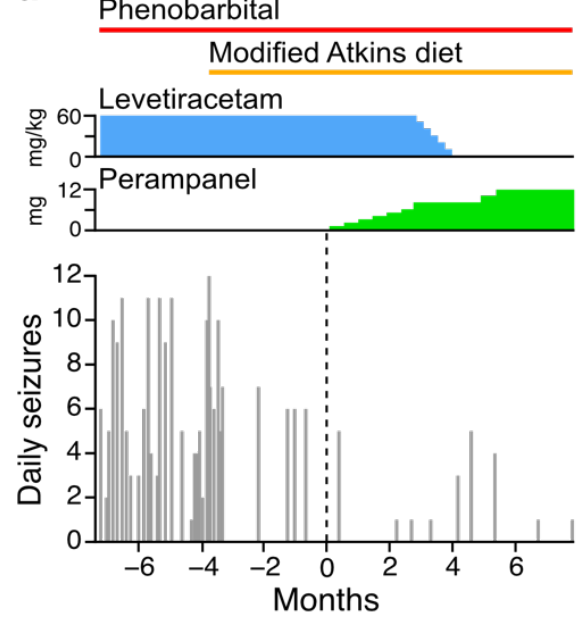

30 months, asleep EEG

Figure 6. Functional and clinical impact of perampanel.

a) Representative GluA2(Q)/ 22 (black) and GluA2(Q) A643V/ץ2 currents (purple) with inhibition by 3 $\mu \mathrm{M}$ perampanel (pale traces). Note the run-up in steady-state current seen with the variant. $\mathbf{b}$ )

Concentration inhibition curves demonstrating decreased potency of PMP against the A643V variant.

Symbols and error bars indicate mean values with s.e.m., and the solid lines are fits to the Hill equation, yielding the indicated $I C_{50}$ values. Table 2 reports the statistical analysis of $I C_{50}$ values 
medRxiv preprint doi: https://doi.org/10.1101/2022.03.01.22271646; this version posted March 4, 2022. The copyright holder for this preprint (which was not certified by peer review) is the author/funder, who has granted medRxiv a license to display the preprint in perpetuity. It is made available under a CC-BY 4.0 International license .

obtained from separate fits of the data from individual patches. c) Crystal structure of a GluA2(Q) receptor with perampanel bound, showing the binding site adjacent to A643, and the F644 that interacts the phenyl ring of perampanel (PDB: 5L1F [16]). d) Number of parent-reported daily seizures in the months before and after commencement of perampanel treatment (at 0 months). Colored bars and plots denote the timing of anti-seizure medications. Phenobarbital ( $6 \mathrm{mg} / \mathrm{kg}$ daily) is currently being weaned, while the Modified Atkins diet is being maintained. Following the introduction of perampanel, levetiracetam was gradually withdrawn. e, f) EEG at 30 months of age following treatment with perampanel for 3 months. The awake $(e)$ and sleep $(f)$ interictal patterns remain slow and disorganized, with multifocal spikes in sleep, consistent with an epileptic encephalopathy with ongoing risk for seizures.

\section{Clinical introduction of perampanel}

Following the introduction of the modified Atkins diet at 24 months the patient displayed an initial drop in seizure number and frequency, although occasional clusters of 6 or more seizures persisted (Fig 6d). Our functional data demonstrate that, while perampanel has a reduced potency against the variant, it is an effective blocker at high doses. Following confirmation of a GRIA2 GoF mechanism, adjunctive treatment with perampanel was initiated at 27 months of age. Perampanel was introduced at $1 \mathrm{mg}$ daily, with gradual uptitration of the dose. Perampanel introduction was associated with a further reduction in seizure frequency, allowing the patient to be successfully weaned from levetiracetam and he is gradually being weaned from phenobarbital. At 32 months of age the modified Atkins was supplemented with MCT oil [26].

Following the introduction of perampanel the rate of developmental gains, as reported by the patient's occupational therapist, accelerated. He gained the ability to sit independently and weight-bear in quadruped and is ambulating with a gait-trainer. Fine motor progression was also noted, including gains in grasping and reaching. His visual attention has significantly improved in terms of both eye contact and facial recognition. He is developing communication skills, and can both follow simple commands and verbally respond consistently to "yes" and "no" questions. Constipation, vomiting and failure to thrive have resolved and current weight (34 months) has recovered (from the $0.07 \%$-ile at 20 months) to 
medRxiv preprint doi: https://doi.org/10.1101/2022.03.01.22271646; this version posted March 4, 2022. The copyright holder for this preprint (which was not certified by peer review) is the author/funder, who has granted medRxiv a license to display the preprint in perpetuity. It is made available under a CC-BY 4.0 International license .

the $15.8 \%$-ile. The patient has suffered no adverse effects of perampanel and has been successfully titrated to the maximum dose of $12 \mathrm{mg}$ daily. His family reports a significant improvement in baseline irritability, and in particular, improved mood with consistent smiling and purposeful laughing following his perampanel dose, behaviors that were not present prior to perampanel. Nonetheless, the EEG performed at 30 months ( 3 months after starting perampanel, and 6 months after the onset of the modified Atkins diet) remained slow and disorganized, with multifocal spikes predominantly in the bilateral posterior and left temporal regions, suggestive of an epileptic encephalopathy with ongoing risk for recurrent seizures (Fig 6e,f). Consistent with this, two additional clusters of asymmetric tonic seizures associated with a viral illness and teething, respectively, were observed 4-5 months after perampanel initiation. These were successfully rescued with additional phenobarbital.

\section{Discussion}

\section{GRIA disorder}

GRIA disorder is an emerging neurological disease with over 100 published variants identified across the four GRIA genes [1]. Most patients with GRIA disorder display intellectual disability and developmental delay, accompanied, in many cases, with ASD and seizures. However, beyond these broad groupings there is great variety in the nature and onset of symptoms. Our patient exhibited some of the features previously reported for various different individuals with GRIA2 disorder: for example, in the onset of symptoms at $\sim 6$ months, the presence of myoclonic seizures and developmental delay [7]. However, certain of our patient's symptoms had not previously been reported; these include failure-tothrive, associated with gastrointestinal symptoms. Our study establishes that GRIA2 A643V is a GoF variant - a previously unreported molecular phenotype which could be expected to account for the neurological symptoms observed. 
medRxiv preprint doi: https://doi.org/10.1101/2022.03.01.22271646; this version posted March 4, 2022. The copyright holder for this preprint (which was not certified by peer review) is the author/funder, who has granted medRxiv a license to display the preprint in perpetuity. It is made available under a CC-BY 4.0 International license .

The diverse symptoms of GRIA disorder likely stem from the identity of the AMPAR subunit involved in each case and the varied functional impact of the various mutations. Where functional analysis of variants has been performed, studies have identified both GoF changes (in GRIA1 [6] and GRIA3 [27, 28], and LoF changes (in GRIA2 [7] and GRIA3 [5, $29,30]$. For GRIA2, a wide variety of causative defects have been described. These include missense [7, 31], nonsense [7, 32], frame shift, truncation, splice site and in-frame deletion variants [7], as well as haploinsufficiency [7, 33-35]. Of the ten GRIA2 missense variants that have been functionally examined, six were reported to be LoF, three displayed behavior indistinguishable from that of wild-type, while one (a variant at the $Q / R$ site) led to the production of $\mathrm{Ca}^{2+}$-permeable GluA2-containing receptors [7]. Our case represents the first identification of a GRIA2 GoF variant featuring prolonged activation and increased glutamate potency.

The A643V variant affects the most highly conserved sequence in the ionotropic glutamate receptor superfamily, namely the SYTANLAAF motif which is found towards the extracellular part of the M3 transmembrane domain. This motif forms the upper channel gate, which in the closed receptor contains all four Ala643 residues of the tetramer in close proximity [36]. As these Ala643 residues are tightly packed by the surrounding residues, the introduction of a larger sidechain (valine) is expected to destabilize the closed gate. It follows that channel closure by deactivation is likely to be less favorable and slower, while the degree of desensitization would be reduced. We observed these effects not only for homomeric GluA2(Q), but also for heteromeric receptors containing just two GluA2(R) A643V subunits, and for all receptors containing the auxiliary protein TARP $\mathrm{Y} 2$. The increased potency of glutamate at homomeric GluA2(Q) variant receptors might result from the destabilized gate being more fully opened by subsaturating glutamate concentrations [37]. Interestingly, A643V does not produce the constitutive channel gating that occurs with threonine variants at the analogous site in other subunits $[6,38,39]$. 
medRxiv preprint doi: https://doi.org/10.1101/2022.03.01.22271646; this version posted March 4, 2022. The copyright holder for this preprint (which was not certified by peer review) is the author/funder, who has granted medRxiv a license to display the preprint in perpetuity. It is made available under a CC-BY 4.0 International license .

\section{Perampanel}

Having identified A643V as a GoF variant, we investigated perampanel with a view to its possible therapeutic use. We found the drug to be much less potent on GluA2 A643V than on the wild-type receptors. This reduction is likely due to the proximity of the perampanel binding site to position 643 - any rearrangement of the outer M3 helix to accommodate Val643 will displace the adjacent Phe644 which is the most indispensable of the amino acids that form the perampanel binding site [16]. This means that in our patient, the inhibition of GluA2 A643V-containing AMPARs by perampanel would be expected to be less than that of AMPARs containing only wild-type GluA1-4 subunits.

Although drugs that bind to alternative parts of the AMPAR could, in theory, display improved selectivity against GluA2 A643V, no candidate molecules are available in the clinic. Interestingly, however, one component of the medium chain triglyceride (MCT) ketogenic diet, an established therapy for drug-resistant epilepsy [26], may act, in part, through inhibition of AMPARs. Specifically, seizure control by decanoic acid, a constituent of the MCT ketogenic diet [40], has been shown to involve inhibition of AMPARs through binding at a site distinct from that of perampanel [41]. Indeed, when used in combination, perampanel and decanoic acid act synergistically to inhibit AMPARs and provide enhanced suppression of seizure-like activity recorded in vitro from rodent and human brain tissue [42]. The current treatment plan for our patient - a modified Atkins diet (with MCT oil supplementation) alongside perampanel - would be expected to inhibit AMPARs through actions at two different sites, and this may contribute to its success despite the limited relative potency of perampanel against A643V variant receptors. However, it should be noted that in our patient, MCT oil supplementation of the modified Atkins diet was not initiated until 2 months after the introduction of perampanel. Another fatty acid, trans-4butylcyclohexanxe carboxylic acid (4-BCCA), a cyclic derivative of octanoic acid, has also been shown to be effective against epileptiform activity in vitro [43] and bind to AMPARs at a site different from that of perampanel [44]. In future studies it will be of interest to assess the 
medRxiv preprint doi: https://doi.org/10.1101/2022.03.01.22271646; this version posted March 4, 2022. The copyright holder for this preprint (which was not certified by peer review) is the author/funder, who has granted medRxiv a license to display the preprint in perpetuity. It is made available under a CC-BY 4.0 International license .

efficacy of a range of organic molecules including decanoic acid and 4-BCCA (alone or in combination with perampanel) as blockers of the A643V variant.

Genetic testing to identify monogenic epilepsies can potentially reveal appropriate therapeutic targets. Our study demonstrates that the potential benefits of such precision medicine can justify the time and effort involved. In our case, although previous GRIA2 variants were identified as LoF [7] , coupling the results of the extended genetic screen with detailed functional study highlighted the NAM perampanel as a logical candidate for therapy. Adding perampanel to our patient's ongoing regimen was successful in reducing seizure number and has allowed weaning from levetiracetam (complete) and phenobarbital (ongoing). Notably, the gastrointestinal symptoms and failure to thrive also resolved. Whether this could reflect perampanel-inhibition of overactive variant GluA2-containing receptors, either centrally or in the peripheral/enteric nervous system, is unclear.

Commonly reported side-effects associated with perampanel use include impairments such as dizziness and sedation, as well as behavioral side effects such as negative mood alteration and aggression $[45,46]$. Remarkably, our patient displayed quite the opposite behavior; he has shown increased alertness with improving fine motor control while his reported mood is significantly improved. A parsimonious explanation for this would be that, when typically prescribed, perampanel produces global underactivity of AMPARs while in a patient with AMPAR GoF it may instead promote a normalization of AMPAR-mediated excitation. Whatever the explanation, in the case of GRIA2 GoF, perampanel not only reduces seizures but appears to facilitate developmental gain. This raises the possibility that other patients with GRIA GoF variants might benefit from perampanel treatment, even in the absence of epilepsy. 
medRxiv preprint doi: https://doi.org/10.1101/2022.03.01.22271646; this version posted March 4, 2022. The copyright holder for this preprint (which was not certified by peer review) is the author/funder, who has granted medRxiv a license to display the preprint in perpetuity.

\section{Materials and Methods}

Clinical details. The study was deemed to be 'not regulated' by the Institutional Review Board (IRB) of the University of Michigan; publishing the clinical findings from a single individual does not fit the definition of human subjects research requiring IRB approval (per 45 CFR 46, 21 CFR 56 and University of Michigan policy). Written informed consent for genetic testing and publication was obtained from the patient's parents. Trio genetic analysis was performed by GeneDX (Gaithersburg, MD) using the EpiXpanded Panel (https://www.genedx.com/tests/detail/epixpanded-panel-835). Treatment outcomes were obtained from neurological assessment, interviews with the patient's parents, and evaluations by the patient's occupational therapist.

Heterologous expression. We expressed recombinant human AMPAR subunits and TARP Y2 (kind gifts from Dimitri Kullmann, UCL Queen Square Institute of Neurology, London, and Michael Maher, Janssen Research \& Development L.L.C., San Diego, respectively), and EGFP, in HEK293 cells. These were maintained under standard protocols, as described previously [37]. GluA2 subunit cDNA was of the flip splice form and was R/G unedited. The GluA2 A643V point mutation was produced using standard PCR protocols. AMPAR/TARP combinations were transfected at a cDNA ratio of 1:1. For GluA1/2 receptors, the subunits were expressed at a ratio of 1:2. Transient transfection was performed using Lipofectamine 2000 (Life Technologies), and electrophysiological recordings were performed 18-48 h later.

Electrophysiology. Recordings were made with an external solution containing $145 \mathrm{mM}$ $\mathrm{NaCl}, 2.5 \mathrm{mM} \mathrm{KCl}, 1 \mathrm{mM} \mathrm{CaCl} 2,1 \mathrm{mM} \mathrm{MgCl}$, and $10 \mathrm{mM}$ HEPES, pH 7.3. Patch-clamp electrodes were pulled from borosilicate glass $(1.5 \mathrm{~mm}$ o.d., $0.86 \mathrm{~mm}$ i.d.; Harvard Apparatus) and fire polished to a final resistance of 8-12 $\mathrm{M} \Omega$. The internal solution contained $145 \mathrm{mM} \mathrm{CsCl}, 2.5 \mathrm{mM} \mathrm{NaCl}, 1 \mathrm{mM}$ Cs-EGTA, 4 mM MgATP, and $10 \mathrm{mM}$ HEPES (pH 7.3 with $\mathrm{CsOH}$ ) and was supplemented with $100 \mu \mathrm{M}$ spermine tetrahydrochloride or $100 \mu \mathrm{M}$ NASPM for recordings from GluA2(Q) or GluA1/2, respectively. Recordings were made from 
medRxiv preprint doi: https://doi.org/10.1101/2022.03.01.22271646; this version posted March 4, 2022. The copyright holder for this preprint (which was not certified by peer review) is the author/funder, who has granted medRxiv a license to display the preprint in perpetuity. It is made available under a CC-BY 4.0 International license .

outside-out patches at $22-25^{\circ} \mathrm{C}$ using an Axopatch 200B amplifier (Molecular Devices). Currents were recorded at $-60 \mathrm{mV}$ for GluA2(Q) or $+60 \mathrm{mV}$ for GluA1/2, low-pass filtered at $10 \mathrm{kHz}$, and digitized at $20 \mathrm{kHz}$ using an NI USB-6341 (National Instruments) interface with Strathclyde Electrophysiology Software WINWCP (John Dempster, University of Strathclyde, Glasgow UK).

Rapid agonist application to excised patches. Rapid agonist application was achieved by switching between continuously flowing solutions. Solution exchange was achieved by moving an application tool made from theta glass (Hilgenberg) or triple barreled glass (Vitrocom) mounted on a piezoelectric translator (Physik Instrumente). The 10-90\% exchange times, assessed by jumping open electrodes into a diluted solution and observing junction potential changes, were between 150 and $300 \mu$ s.

Experiments to assess dose response relationships for glutamate were performed using triple barreled glass. For experiments with cyclothiazide, each barrel contained a different glutamate concentration. In experiments to assess the glutamate $E C_{50}$ of responses to fast jumps, the central barrel and left-hand barrel contained control and $10 \mathrm{mM}$ glutamate solutions throughout, while the concentration in the right-hand barrel was varied. By alternately jumping into the streams from the left and right barrels, any effect of rundown was negated through normalization of the test response to the $10 \mathrm{mM}$ glutamate response. Potency of inhibition by perampanel was assessed by comparing initial peak responses produced by 500 ms fast jumps into $10 \mathrm{mM}$ glutamate in the absence or continuous presence of different concentrations of perampanel.

Data analysis. Records were analyzed using Igor Pro 6.35 (Wavemetrics) with Neuromatic 2.8 [47]. Entry into desensitization (500 ms application of $10 \mathrm{mM}$ glutamate) and current deactivation (1-2 ms application of $10 \mathrm{mM}$ glutamate) were fitted with the sum of two exponentials and the weighted time constants ( $\mathrm{T}_{\mathrm{w}, \text { des }}$ and $\left.\mathrm{T}_{\mathrm{w}, \text { deact }}\right)$ calculated, according to: 
medRxiv preprint doi: https://doi.org/10.1101/2022.03.01.22271646; this version posted March 4, 2022. The copyright holder for this preprint

$$
\tau_{\mathrm{w}}=\tau_{\mathrm{f}}\left(\frac{A_{\mathrm{f}}}{A_{\mathrm{f}}+A_{\mathrm{s}}}\right)+\tau_{\mathrm{s}}\left(\frac{A_{\mathrm{s}}}{A_{\mathrm{f}}+A_{\mathrm{s}}}\right)
$$

where $A_{\mathrm{f}}$ and $\tau_{\mathrm{f}}$ are the amplitude and time constant of the fast component and $A_{\mathrm{s}}$ and $\tau_{\mathrm{s}}$ are the amplitude and time constant of the slow component.

Non-stationary fluctuation analysis was performed on the decaying phase of currents evoked by $500 \mathrm{~ms}$ applications of $10 \mathrm{mM}$ glutamate, as previously described [48]. The variance for each successive pair of current responses was calculated and the single-channel current $(i)$ and total number of channels $(N)$ were then determined by plotting the ensemble variance $\left(\sigma^{2}\right)$ against mean current $(\bar{l})$ and fitting with a parabolic function:

$$
\sigma^{2}=i \bar{I}-\frac{\bar{I}^{2}}{N}+\sigma_{\mathrm{B}}^{2}
$$

where $\sigma_{\mathrm{B}}^{2}$ is the background variance. The weighted mean single-channel conductance was calculated from the single-channel current and the holding potential.

$E C_{50}$ and $I C_{50}$ values were derived by fitting the Hill equation:

$$
I=\frac{I_{\max }}{1+\left(\frac{E C_{50}}{[\text { drug }]}\right)^{n_{\mathrm{H}}}}
$$

where $I_{\max }$ is the peak of the fit, $E C_{50}$ is the concentration producing the half-maximal response, $n_{\mathrm{H}}$ is the Hill coefficient and [drug] refers to the concentration of either glutamate or perampanel. Before pooling the data, the $I_{\max }$ value derived from the fit for each patch was used to rescale the individual datasets. The rescaled values were then averaged and refit for display purposes only.

Data presentation and statistical analysis. Statistical analysis was performed using $R$ (version 4.1.1, the R Foundation for Statistical Computing, https://www.r-project.org/) and R Studio (version 1.4.1717, RStudio). Summary data are presented in the text as mean \pm standard error (s.e.m.) from n patches. The data for the different measures from wild-type and variant receptors are also presented in Table 1 and Table 2, together with unpaired 
medRxiv preprint doi: https://doi.org/10.1101/2022.03.01.22271646; this version posted March 4, 2022. The copyright holder for this preprint (which was not certified by peer review) is the author/funder, who has granted medRxiv a license to display the preprint in perpetuity. It is made available under a CC-BY 4.0 International license .

mean differences and their $95 \%$ confidence intervals. Bias corrected and accelerated (BCa) confidence intervals were calculated from 5000 bootstrap resamples using the dabestr package in $\mathrm{R}$ [49]. Normality was not tested statistically but gauged from density histograms and/or quantile-quantile plots. All p-values were calculated using a non-parametric two-sided approximate permutation t-test, with 10000 bootstrap replicates using the Coin package in $\mathrm{R}$ [50]. No statistical test was used to predetermine sample sizes; these were based on standards of the field.

\section{Acknowledgements}

This work was supported by a Medical Research Council Programme Grant to Mark Farrant and Stuart G. Cull-Candy [Grant MR/T002506/1].

We thank the patient's family for their generous collaboration and the CureGRIN Foundation (https://curegrin.org) for facilitating this interaction. We are grateful for the assistance of Casey Bross. We thank Dimitri Kullmann, Michael Maher and Henry Holden for helpful materials and/or discussion.

\section{References}

1. Hansen KB, Wollmuth LP, Bowie D, Furukawa H, Menniti FS, Sobolevsky AI, et al. Structure, Function, and Pharmacology of Glutamate Receptor Ion Channels. Pharmacol Rev. 2021;73(4):298-487. Epub 2021/11/11. doi: 10.1124/pharmrev.120.000131. PubMed PMID: 34753794.

2. Kessels HW, Malinow R. Synaptic AMPA receptor plasticity and behavior. Neuron. 2009;61(3):340-50. Epub 2009/02/17. doi: 10.1016/j.neuron.2009.01.015. PubMed PMID: 19217372; PubMed Central PMCID: PMCPMC3917551.

3. Diering G, Huganir R. The AMPA Receptor Code of Synaptic Plasticity. Neuron. 2018;100(2):314-29. doi: 10.1016/j.neuron.2018.10.018. PubMed PMID: 30359599.

4. Martin S, Chamberlin A, Shinde D, Hempel M, Strom T, Schreiber A, et al. De Novo Variants in GRIA4 Lead to Intellectual Disability with or without Seizures and Gait 
medRxiv preprint doi: https://doi.org/10.1101/2022.03.01.22271646; this version posted March 4, 2022. The copyright holder for this preprint (which was not certified by peer review) is the author/funder, who has granted medRxiv a license to display the preprint in perpetuity. It is made available under a CC-BY 4.0 International license .

Abnormalities. Am J Hum Genet. 2017;101(6):1013-20. doi: 10.1016/j.ajhg.2017.11.004. PubMed PMID: 29220673.

5. Davies B, Brown L, Cais O, Watson J, Clayton A, Chang V, et al. A point mutation in the ion conduction pore of AMPA receptor GRIA3 causes dramatically perturbed sleep patterns as well as intellectual disability. Hum Mol Genet. 2017;26(20):3869-82. doi: 10.1093/hmg/ddx270. PubMed PMID: 29016847.

6. Geisheker MR, Heymann G, Wang T, Coe BP, Turner TN, Stessman HAF, et al. Hotspots of missense mutation identify neurodevelopmental disorder genes and functional domains. Nat Neurosci. 2017;20(8):1043-51. Epub 2017/06/20. doi: 10.1038/nn.4589. PubMed PMID: 28628100; PubMed Central PMCID: PMCPMC5539915.

7. Salpietro V, Dixon C, Guo H, Bello O, Vandrovcova J, Efthymiou S, et al. AMPA receptor GluA2 subunit defects are a cause of neurodevelopmental disorders. Nat Commun. 2019;10(1):3094. doi: 10.1038/s41467-019-10910-w. PubMed PMID: 31300657.

8. Schwenk J, Baehrens D, Haupt A, Bildl W, Boudkkazi S, Roeper J, et al. Regional diversity and developmental dynamics of the AMPA-receptor proteome in the mammalian brain. Neuron. 2014;84(1):41-54. doi: 10.1016/j.neuron.2014.08.044. PubMed PMID: 25242221.

9. Wenthold R, Petralia R, Blahos J I, Niedzielski A. Evidence for multiple AMPA receptor complexes in hippocampal CA1/CA2 neurons. J Neurosci. 1996;16(6):1982-9. PubMed PMID: 8604042.

10. Lu W, Shi Y, Jackson AC, Bjorgan K, During MJ, Sprengel R, et al. Subunit composition of synaptic AMPA receptors revealed by a single-cell genetic approach. Neuron. 2009;62(2):254-68. doi: 10.1016/j.neuron.2009.02.027. PubMed PMID: 19409270.

11. Zhao Y, Chen S, Swensen A, Qian W, Gouaux E. Architecture and subunit arrangement of native AMPA receptors elucidated by cryo-EM. Science. 2019;364(6438):355-62. doi: 10.1126/science.aaw8250. PubMed PMID: 30975770. 
medRxiv preprint doi: https://doi.org/10.1101/2022.03.01.22271646; this version posted March 4, 2022. The copyright holder for this preprint (which was not certified by peer review) is the author/funder, who has granted medRxiv a license to display the preprint in perpetuity. It is made available under a CC-BY 4.0 International license .

12. Burnashev N, Monyer H, Seeburg P, Sakmann B. Divalent ion permeability of AMPA receptor channels is dominated by the edited form of a single subunit. Neuron. 1992;8(1):189-98. doi: 10.1016/0896-6273(92)90120-3. PubMed PMID: 1370372.

13. Petrovski S, Wang Q, Heinzen EL, Allen AS, Goldstein DB. Genic intolerance to functional variation and the interpretation of personal genomes. PLoS Genet. 2013;9(8):e1003709. Epub 2013/08/31. doi: 10.1371/journal.pgen.1003709. PubMed PMID: 23990802; PubMed Central PMCID: PMCPMC3749936.

14. Hibi S, Ueno K, Nagato S, Kawano K, Ito K, Norimine Y, et al. Discovery of 2-(2-oxo-1phenyl-5-pyridin-2-yl-1,2-dihydropyridin-3-yl)benzonitrile (perampanel): a novel, noncompetitive alpha-amino-3-hydroxy-5-methyl-4-isoxazolepropanoic acid (AMPA) receptor antagonist. J Med Chem. 2012;55(23):10584-600. Epub 2012/11/28. doi: 10.1021/jm301268u. PubMed PMID: 23181587.

15. Mytinger JR, Hussain SA, Islam MP, Millichap JJ, Patel AD, Ryan NR, et al. Improving the inter-rater agreement of hypsarrhythmia using a simplified EEG grading scale for children with infantile spasms. Epilepsy Res. 2015;116:93-8. Epub 2015/08/19. doi: 10.1016/j.eplepsyres.2015.07.008. PubMed PMID: 26280806.

16. Yelshanskaya MV, Singh AK, Sampson JM, Narangoda C, Kurnikova M, Sobolevsky Al. Structural Bases of Noncompetitive Inhibition of AMPA-Subtype Ionotropic Glutamate Receptors by Antiepileptic Drugs. Neuron. 2016;91(6):1305-15. doi: 10.1016/j.neuron.2016.08.012. PubMed PMID: 27618672.

17. Klein RM, Howe JR. Effects of the lurcher mutation on GluR1 desensitization and activation kinetics. J Neurosci. 2004;24(21):4941-51. Epub 2004/05/28. doi: 10.1523/JNEUROSCI.0660-04.2004. PubMed PMID: 15163686; PubMed Central PMCID: PMCPMC6729373.

18. Adzhubei IA, Schmidt S, Peshkin L, Ramensky VE, Gerasimova A, Bork P, et al. A method and server for predicting damaging missense mutations. Nat Methods. 2010;7(4):248-9. Epub 2010/04/01. doi: 10.1038/nmeth0410-248. PubMed PMID: 20354512; PubMed Central PMCID: PMCPMC2855889. 
medRxiv preprint doi: https://doi.org/10.1101/2022.03.01.22271646; this version posted March 4, 2022. The copyright holder for this preprint (which was not certified by peer review) is the author/funder, who has granted medRxiv a license to display the preprint in perpetuity. It is made available under a CC-BY 4.0 International license .

19. Ng PC, Henikoff S. Predicting deleterious amino acid substitutions. Genome Res. 2001;11(5):863-74. Epub 2001/05/05. doi: 10.1101/gr.176601. PubMed PMID: 11337480; PubMed Central PMCID: PMCPMC311071.

20. Wu Y, Li R, Sun S, Weile J, Roth FP. Improved pathogenicity prediction for rare human missense variants. Am J Hum Genet. 2021;108(10):1891-906. Epub 2021/09/23. doi: 10.1016/j.ajhg.2021.08.012. PubMed PMID: 34551312; PubMed Central PMCID: PMCPMC8546039.

21. Yu J, Rao P, Clark S, Mitra J, Ha T, Gouaux E. Hippocampal AMPA receptor assemblies and mechanism of allosteric inhibition. Nature. 2021;594(7863):448-53. Epub 2021/05/14. doi: 10.1038/s41586-021-03540-0. PubMed PMID: 33981040; PubMed Central PMCID: PMCPMC8270219.

22. Coombs ID, Bats C, Sexton CA, Cull-Candy SG, Farrant M. Intracellular NASPM allows an unambiguous functional measure of GluA2-lacking calcium-permeable AMPA receptor prevalence. bioRxiv. 2021:2021.02.18.431828. doi: 10.1101/2021.02.18.431828.

23. Coombs I, Cull-Candy S. Transmembrane AMPA receptor regulatory proteins and AMPA receptor function in the cerebellum. Neuroscience. 2009;162(3):656-65. doi: 10.1016/j.neuroscience.2009.01.004. PubMed PMID: 19185052.

24. Greger I, Watson J, Cull-Candy S. Structural and Functional Architecture of AMPA-Type Glutamate Receptors and Their Auxiliary Proteins. Neuron. 2017;94(4):713-30. doi: 10.1016/j.neuron.2017.04.009. PubMed PMID: 28521126.

25. Tomita S, Adesnik H, Sekiguchi M, Zhang W, Wada K, Howe JR, et al. Stargazin modulates AMPA receptor gating and trafficking by distinct domains. Nature. 2005;435(7045):1052-8. doi: 10.1038/nature03624. PubMed PMID: 15858532.

26. Neal EG, Chaffe H, Schwartz RH, Lawson MS, Edwards N, Fitzsimmons G, et al. A randomized trial of classical and medium-chain triglyceride ketogenic diets in the treatment of childhood epilepsy. Epilepsia. 2009;50(5):1109-17. Epub 2008/12/05. doi: 10.1111/j.1528-1167.2008.01870.x. PubMed PMID: 19054400. 
medRxiv preprint doi: https://doi.org/10.1101/2022.03.01.22271646; this version posted March 4, 2022. The copyright holder for this preprint (which was not certified by peer review) is the author/funder, who has granted medRxiv a license to display the preprint in perpetuity. It is made available under a CC-BY 4.0 International license .

27. Sun J, Chen J, Ayala Valenzuela F, Brown C, Masser-Frye D, Jones M, et al. X-linked neonatal-onset epileptic encephalopathy associated with a gain-of-function variant p.R660T in GRIA3. PLoS Genet. 2021;17(6):e1009608. doi:

10.1371/journal.pgen.1009608. PubMed PMID: 34161333.

28. Hamanaka K, Miyoshi K, Sun JH, Hamada K, Komatsubara T, Saida K, et al. Amelioration of a neurodevelopmental disorder by carbamazepine in a case having a gain-of-function GRIA3 variant. Hum Genet. 2022;141(2):283-93. Epub 2022/01/16. doi: 10.1007/s00439-021-02416-7. PubMed PMID: 35031858.

29. Wu Y, Arai AC, Rumbaugh G, Srivastava AK, Turner G, Hayashi T, et al. Mutations in ionotropic AMPA receptor 3 alter channel properties and are associated with moderate cognitive impairment in humans. Proc Natl Acad Sci U S A. 2007;104(46):18163-8. Epub 2007/11/09. doi: 10.1073/pnas.0708699104. PubMed PMID: 17989220; PubMed Central PMCID: PMCPMC2084314.

30. Piard J, Bereau M, XiangWei W, Wirth T, Amsallem D, Buisson L, et al. The GRIA3 c.2477G > A Variant Causes an Exaggerated Startle Reflex, Chorea, and Multifocal Myoclonus. Mov Disord. 2020;35(7):1224-32. Epub 2020/05/06. doi: 10.1002/mds.28058. PubMed PMID: 32369665.

31. Zhou B, Zhang C, Zheng L, Wang Z, Chen X, Feng X, et al. Case Report: A Novel De Novo Missense Mutation of the GRIA2 Gene in a Chinese Case of Neurodevelopmental Disorder With Language Impairment. Front Genet. 2021;12:794766. Epub 2021/12/14. doi: 10.3389/fgene.2021.794766. PubMed PMID: 34899870; PubMed Central PMCID: PMCPMC8655903.

32. Alkelai A, Shohat S, Greenbaum L, Schechter T, Draiman B, Chitrit-Raveh E, et al. Expansion of the GRIA2 phenotypic representation: a novel de novo loss of function mutation in a case with childhood onset schizophrenia. J Hum Genet. 2021;66(3):33943. Epub 2020/09/20. doi: 10.1038/s10038-020-00846-1. PubMed PMID: 32948840.

33. Tzschach A, Menzel C, Erdogan F, Istifli ES, Rieger M, Ovens-Raeder A, et al. Characterization of an interstitial $4 q 32$ deletion in a patient with mental retardation and a 
medRxiv preprint doi: https://doi.org/10.1101/2022.03.01.22271646; this version posted March 4, 2022. The copyright holder for this preprint (which was not certified by peer review) is the author/funder, who has granted medRxiv a license to display the preprint in perpetuity. It is made available under a CC-BY 4.0 International license .

complex chromosome rearrangement. Am J Med Genet A. 2010;152A(4):1008-12. Epub 2010/04/02. doi: 10.1002/ajmg.a.33343. PubMed PMID: 20358617.

34. Hackmann K, Matko S, Gerlach EM, von der Hagen M, Klink B, Schrock E, et al. Partial deletion of GLRB and GRIA2 in a patient with intellectual disability. Eur J Hum Genet. 2013;21(1):112-4. Epub 2012/06/07. doi: 10.1038/ejhg.2012.97. PubMed PMID: 22669415; PubMed Central PMCID: PMCPMC3522202.

35. Calcia A, Gai G, Di Gregorio E, Talarico F, Naretto VG, Migone N, et al. Bilaterally cleft lip and bilateral thumb polydactyly with triphalangeal component in a patient with two de novo deletions of HSA 4q32 and 4q34 involving PDGFC, GRIA2, and FBXO8 genes. Am J Med Genet A. 2013;161A(10):2656-62. Epub 2013/09/17. doi: 10.1002/ajmg.a.36146. PubMed PMID: 24038848.

36. Sobolevsky A, Rosconi M, Gouaux E. X-ray structure, symmetry and mechanism of an AMPA-subtype glutamate receptor. Nature. 2009;462(7274):745-56. doi: 10.1038/nature08624. PubMed PMID: 19946266.

37. Coombs I, MacLean D, Jayaraman V, Farrant M, Cull-Candy S. Dual Effects of TARP Y2 on Glutamate Efficacy Can Account for AMPA Receptor Autoinactivation. Cell Rep. 2017;20(5):1123-35. doi: 10.1016/j.celrep.2017.07.014. PubMed PMID: 28768197.

38. Zuo J, De Jager PL, Takahashi KA, Jiang W, Linden DJ, Heintz N. Neurodegeneration in Lurcher mice caused by mutation in delta2 glutamate receptor gene. Nature. 1997;388(6644):769-73. Epub 1997/08/21. doi: 10.1038/42009. PubMed PMID: 9285588.

39. Guzman YF, Ramsey K, Stolz JR, Craig DW, Huentelman MJ, Narayanan V, et al. A gain-of-function mutation in the GRIK2 gene causes neurodevelopmental deficits. Neurol Genet. 2017;3(1):e129. Epub 2017/02/10. doi: 10.1212/NXG.0000000000000129. PubMed PMID: 28180184; PubMed Central PMCID: PMCPMC5286855.

40. Chang P, Terbach N, Plant N, Chen PE, Walker MC, Williams RS. Seizure control by ketogenic diet-associated medium chain fatty acids. Neuropharmacology. 2013;69:105- 
medRxiv preprint doi: https://doi.org/10.1101/2022.03.01.22271646; this version posted March 4, 2022. The copyright holder for this preprint (which was not certified by peer review) is the author/funder, who has granted medRxiv a license to display the preprint in perpetuity. It is made available under a CC-BY 4.0 International license .

14. Epub 2012/11/28. doi: 10.1016/j.neuropharm.2012.11.004. PubMed PMID: 23177536; PubMed Central PMCID: PMCPMC3625124.

41. Chang P, Augustin K, Boddum K, Williams S, Sun M, Terschak J, et al. Seizure control by decanoic acid through direct AMPA receptor inhibition. Brain. 2016;139(Pt 2):431-43. doi: 10.1093/brain/awv325. PubMed PMID: 26608744.

42. Augustin K, Williams S, Cunningham M, Devlin A, Friedrich M, Jayasekera A, et al. Perampanel and decanoic acid show synergistic action against AMPA receptors and seizures. Epilepsia. 2018;59(11):e172-e8. doi: 10.1111/epi.14578. PubMed PMID: 30324610.

43. Chang P, Zuckermann AM, Williams S, Close AJ, Cano-Jaimez M, McEvoy JP, et al. Seizure control by derivatives of medium chain fatty acids associated with the ketogenic diet show novel branching-point structure for enhanced potency. J Pharmacol Exp Ther. 2015;352(1):43-52. Epub 2014/10/19. doi: 10.1124/jpet.114.218768. PubMed PMID: 25326131

44. Yelshanskaya M, Singh A, Narangoda C, Williams R, Kurnikova M, Sobolevsky A. Structural basis of AMPA receptor inhibition by trans-4-butylcyclohexane carboxylic acid. Br J Pharmacol. 2020. doi: 10.1111/bph.15254. PubMed PMID: 32959886.

45. Shah E, Reuber M, Goulding P, Flynn C, Delanty N, Kemp S. Clinical experience with adjunctive perampanel in adult patients with uncontrolled epilepsy: A UK and Ireland multicentre study. Seizure. 2016;34:1-5. Epub 2015/11/30. doi: 10.1016/j.seizure.2015.10.017. PubMed PMID: 26615577.

46. Rugg-Gunn F. Adverse effects and safety profile of perampanel: a review of pooled data. Epilepsia. 2014;55 Suppl 1:13-5. Epub 2014/01/10. doi: 10.1111/epi.12504. PubMed PMID: 24400692.

47. Rothman JS, Silver RA. NeuroMatic: An Integrated Open-Source Software Toolkit for Acquisition, Analysis and Simulation of Electrophysiological Data. Front Neuroinform. 2018;12:14. Epub 2018/04/20. doi: 10.3389/fninf.2018.00014. PubMed PMID: 29670519; PubMed Central PMCID: PMCPMC5893720. 
medRxiv preprint doi: https://doi.org/10.1101/2022.03.01.22271646; this version posted March 4, 2022. The copyright holder for this preprint (which was not certified by peer review) is the author/funder, who has granted medRxiv a license to display the preprint in perpetuity. It is made available under a CC-BY 4.0 International license .

48. Soto D, Coombs I, Kelly L, Farrant M, Cull-Candy S. Stargazin attenuates intracellular polyamine block of calcium-permeable AMPA receptors. Nat Neurosci. 2007;10:1260-7. doi: 10.1038/nn1966. PubMed PMID: 17873873.

49. Ho J, Tumkaya T, Aryal S, Choi H, Claridge-Chang A. Moving beyond P values: data analysis with estimation graphics. Nat Methods. 2019;16(7):565-6. Epub 2019/06/21. doi: 10.1038/s41592-019-0470-3. PubMed PMID: 31217592.

50. Hothorn T, Hornik K, van de Wiel M, Zeileis A. Implementing a class of permutatuon tests:The coin package. Journal of Statistical Software. 2008;28(8). 
medRxiv preprint doi: https://doi.org/10.1101/2022.03.01.22271646; this version posted March 4, 2022. The copyright holder for this preprint (which was not certified by peer review) is the author/funder, who has granted medRxiv a license to display the preprint in perpetuity. It is made available under a CC-BY 4.0 International license .

\section{Supplementary Material}

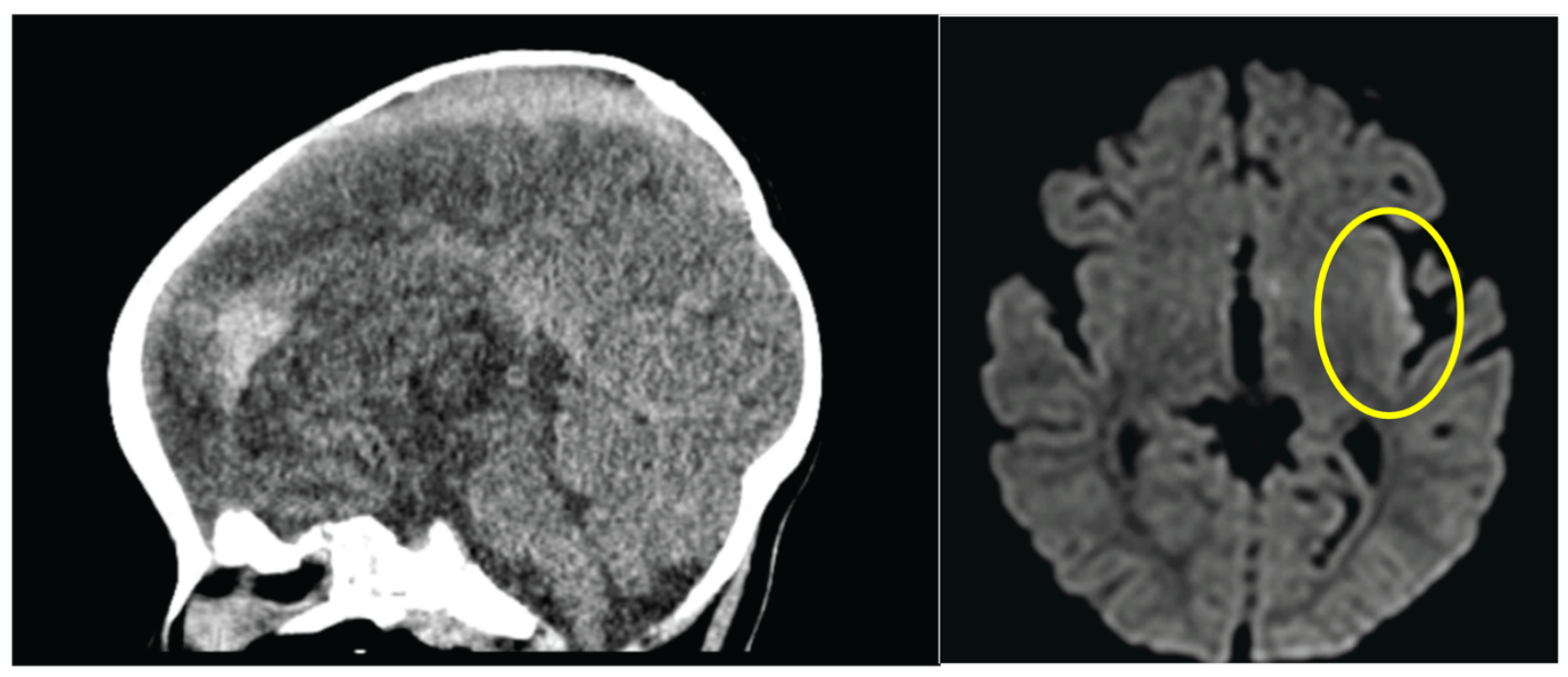

Figure S1: Head imaging at 9 months of age upon presentation for seizures.

Sagittal CT image (left) showed extra-axial hyperdensity along the anterior falx, concerning for a subdural hematoma. Diffusion weighted axial MRI imaging (right) was notable for diffusion restriction along the left insular cortex, likely due to ongoing seizures. 